NBER WORKING PAPER SERIES

\title{
AGING, PENSION REFORM, AND CAPITAL FLOWS: A MULTI-COUNTRY SIMULATION MODEL
}

\author{
Axel Börsch-Supan \\ Alexander Ludwig \\ Joachim Winter \\ Working Paper 11850 \\ http://www.nber.org/papers/w11850 \\ NATIONAL BUREAU OF ECONOMIC RESEARCH \\ 1050 Massachusetts Avenue \\ Cambridge, MA 02138 \\ December 2005
}

We thank Alan Auerbach, Ralph Bryant, Hans Fehr, Alexia Fürnkranz-Prskawetz, Ulrich Grosch, Florian Heiss, Heinz Hermann, Gary Hufbauer, Ulf von Kalkreuth, Florence Legros, Melanie Lührmann, Shinichi Nishiyama, Howard Rosen, Tarmo Valkonen for their helpful remarks on this line of research, and two anonymous referees for their comments, and Holger Herz and Max Flötotto for their excellent research assistance. We also received helpful feedback at many conferences and seminar presentations. This ongoing research project is supported by the VW Foundation, the Deutsche Forschungsgemeinschaft, the Land of Baden Württemberg, the Gesamtverband der deutschen Versicherungswirtschaft, and the US Social Security Administration through grant \#10-P-98363-2 to the National Bureau of Economic Research as part of the SSA Retirement Research Consortium. The findings and conclusions expressed are solely those of the author(s) and do not represent the views of SSA, any agency of the US Government, or the NBER. The views expressed herein are those of the author(s) and do not necessarily reflect the views of the National Bureau of Economic Research.

(C2005 by Axel Börsch-Supan, Alexander Ludwig, Joachim Winter. All rights reserved. Short sections of text, not to exceed two paragraphs, may be quoted without explicit permission provided that full credit, including (C) notice, is given to the source. 
Aging, Pension Reform, and Capital Flows: A Multi-Country Simulation Model

Axel Börsch-Supan, Alexander Ludwig, Joachim Winter

NBER Working Paper No. 11850

December 2005

JEL No. E27, F21, G15, H55, J11

\begin{abstract}
Population aging and pension reform will have profound effects on international capital markets. First, demographic change alters the time path of aggregate savings within each country. Second this process may be amplified when a pension reform shifts old-age provision towards more pre-funding. Third, while the patterns of population aging are similar in most counries, timing and initial conditions differ substantially. Hence, to the extent that capital is internationally mobile, population aging will induce capital flows between countries. All three effects influence the rate of return to capital and interact with the demand for capital in production and with labor supply.

In order to quantify these effects, we develop a computational general equilibrium model. We feed this multi-country overlapping generations model with detailed long-term demographic projections for seven world regions. Our simulations indicate that capital flows from fast-aging regions to the rest of the world will initially be substantial but that trends are reversed when households decumulate savings. We also conclude that closed-economy models of pension reform miss quantitatively important effects of international capital mobility.
\end{abstract}

Axel Börsch-Supan

Department of Economics

University of Mannheim

Building L13, 17

D-68131 Mannheim, GERMANY

and NBER

axel@boersch-supan.de

Alexander Ludwig

Mannheim Research Institute for the Economics of Aging

Mannheim, Germany

Joachim Winter

Department of Economics

University of Munich

Germany

joachim.winter@1rz.uni-muenchen.de 


\section{Introduction}

In the vast majority of countries, populations are aging, and demographic change will continue well into the $21^{\text {st }}$ century. While population aging is common to most countries, extent and timing differ substantially, even within the industrialized countries. It is well known that within each country, demographic change alters the time path of aggregate savings. In a world of closed economies, differential aging will generate international differences in saving rates, investment, and rates of return, in addition to differences for other reasons. These differences are likely to be accentuated when some countries implement fundamental pension reforms that is, shifts towards more pre-funding, induced by the effects of population aging on public pension budgets. In reality, we do not have closed economies but global capital markets. To the extent that capital is internationally mobile, population aging will induce capital flows between countries, and these capital flows will modify the effects of population aging and pension reform in each county vis-à-vis a world of closed economies.

This paper presents a quantitative analysis of the capital and labor market effects and, in particular, of international capital flows induced by differential aging processes across countries and by pension reforms. To this end, we develop a stylized multi-country overlapping generations (OLG) model and project macroeconomic aggregates such as international capital flows over a 70-year horizon, using long-term demographic projections for different sets of countries and regions. Although all countries and regions are modeled symmetrically as large open economies, our presentation focuses on continental Europe as one of the world regions most severely affected by aging. At the same time, pension systems in continental Europe are dominated by still relatively generous pay-as-you-go (PAYG) financed public pensions.

We use a rich modeling framework that allows us to address different strands of the literature. First, we stress the "triangular" relationship between population aging, pension reform, and international capital markets that receives increasing attention in the academic literature, see Börsch-Supan, Ludwig and Winter (2002); INGENUE (2002); Fehr, Jokisch and Kotlikoff (2003, 2004); and Börsch-Supan, Köke and Winter (2004).

Second, our analysis is related to several recent papers that compare implications for capital flows predicted by OLG models with actual current account data (see, e.g., Brooks, 2003; Feroli, 2002; Henriksen, 2002; Domeij and Floden, 2005). Their as well as our analysis show that calibrated OLG models explain a good fraction of the low frequency movements of international capital flows observed in the data. We further show that the existence of PAYG pen- 
sion systems in different world regions adds an additional indirect channel to the interaction between capital flows and demographic change. This channel is of particular importance if countries severely affected by the impact of population aging such as the continental European countries reform their pension systems.

Third, our paper adds to the discussion about the so-called "asset market meltdown hypothesis”. Several articles in the popular press attributed recent turbulences in stock market prices to population aging and raised the fear that an asset market meltdown might occur when the baby boom generation decumulates its assets. In the academic literature, there is no consensus on the asset market meltdown hypothesis (see e.g. Poterba, 2001; Abel, 2001, 2003; and Brooks, 2002). According to our view, closed-economy models often used in the academic literature miss the important fact of international capital flows. We show that, because of international diversification, the dynamics of capital accumulation and rates of return are different from what would be predicted by closed-economy models. One of the main goals of this paper is to analyze and quantify these mechanisms.

Fourth, our paper sheds light on the effects of international diversification on savings behavior and its interaction with pension reforms. This topic receives increasing attention as the pension reform debate progresses. Deardorff (1985) contains an early analysis, and Reisen (2000) provides a comprehensive overview of these issues. Reisen argues that there are pensionimproving benefits of global asset diversification. In a theoretical paper, Pemberton (1999) highlights the importance of international externalities caused by the effects of national pension and savings policies on the world interest rate. Pemberton (2000) goes a step further and shows that an intergenerational Pareto improvement through coordinated pension reforms is possible. We will not tackle this policy issue; our welfare analysis is restricted to the direct welfare effects of population aging, pension reform, and capital mobility.

Finally, from an economic modeling perspective, this paper furthers our understanding of the various interactions among different features of calibrated OLG models. To this end, we present a sensitivity analysis that focuses on the role of including or excluding these features in our model with a particular focus on endogenous labor supply.

Our simulations predict substantial capital flows due to population aging. Population aging results in decreases of saving rates when the baby boomers decumulate their assets. International capital flows follow this trend. The countries most affected by aging such as the European Union will initially be capital exporters, while countries less affected by aging like the United States und other OECD regions will import capital. However, since older households 
decumulate their assets, capital exports from these fast aging countries to the rest of the world decrease and therefore fast aging countries are projected to become capital import countries around the year 2020. Pension reforms with higher degrees of pre-funding are likely to induce more capital exports. They also increase labor supply considerably, while the effects on the rate of return to capital are small. While the rate of return is projected to decline in response to population aging, there is no devastating “asset market meltdown”.

The paper is structured as follows. Section 2 presents empirical evidence on, and theoretical explanations for, the effects of population aging on international capital flows. In Section 3, we present a multi-country OLG model that allows us to evaluate these effects quantitatively. Section 4 describes the calibration of the model and displays indicators of ex post fit. Section 5 contains ex ante simulation results for several pension policy and capital mobility scenarios. Section 6 presents a sensitivity analysis, while Section 7 concludes.

\section{Background: Population aging and international capital flows}

Throughout the world, demographic processes are determined by the demographic transition that is characterized by falling mortality rates followed by a decline in birth rates, resulting in population aging and reducing the population growth rate (in some countries, even turning it negative). While demographic change occurs in almost all countries across the world, extent and timing differ substantially. Europe and some Asian countries have almost passed the closing stages of the demographic transition process while Latin America and Africa are only at the beginning stages (Bloom and Williamson, 1998; United Nations, 2001).

From a macroeconomic point of view, population aging will change the balance between capital and labor, in particular in industrialized countries. Labor supply will be scarce whereas capital will be relatively abundant. This will drive up wages relative to the rate of return on capital, reducing households' incentive to save (if the interest elasticity of saving is positive). In addition, decreasing labor supply reduces demand for investment goods since less capital is needed.

From a microeconomic point of view, the life-cycle theory of consumption and savings (Modigliani and Brumberg, 1954; Ando and Modigliani, 1963) postulates higher saving rates for younger individuals. The aggregation of individual, cohort-specific life-cycle savings profiles therefore leads to a decrease of national saving rates in an aging economy. In a general equilibrium model of forward-looking individuals, it is not only the current demographic structure that alters the time path of aggregate savings, but also future demographic develop- 
ments. In a closed economy, a decline in national savings leads to a decline in investment by definition. In an open economy, the link between these two aggregates is broken to the extent that capital is internationally mobile.

These theoretical mechanisms are reflected in the empirical evidence, see the review by Poterba (2001). Following earlier work by Higgins (1998) and others, Lührmann (2003) investigates whether demographic factors influenced international capital flows in the past, using a broad panel of 141 countries that covers the period 1960-1997. She confirms that crosscountry capital flows are indeed influenced by current demographic variables. Moreover, she shows that future changes in the age structure of countries are important determinants of current saving and investment decisions, a finding that confirms forward-looking household behavior.

The extent of international capital flows induced by population aging depends crucially on the degree of capital mobility. There has been no shortage of empirical research on this issue since the famous puzzle of Feldstein and Horioka (1980). ${ }^{1}$ In their original contribution, Feldstein and Horioka show that national saving and investment rates are highly correlated in virtually all OECD countries. While the coefficient has fallen over time, it is still remarkably high. These findings have been interpreted as an indication that capital is imperfectly mobile. However, there exist several alternative explanations for the observed correlation. For example, high correlations between saving and investment rates are consistent with perfect capital mobility in a growth model with demographic change and technological progress, as pointed out by Obstfeld (1986); see also Baxter and Crucini (1993), Taylor (1994), Obstfeld and Rogoff (1996), and Obstfeld and Rogoff (2000).

Even if capital is fully mobile, this does not necessarily imply that households do actually diversify their portfolios optimally. There is a large empirical literature on 'home bias' in international portfolio choice (e.g., French and Poterba, 1991). Portes and Rey (2005) suggest that information asymmetries across countries are a major source of home bias effects and that capital flows are affected by both geographic and informational proximity. Applied to pension reform policies, this literature suggests that households might be more willing to invest their retirement savings in 'similar' countries such as the EU or OECD countries rather than in developing countries.

\footnotetext{
${ }^{1}$ See Obstfeld and Rogoff (1996) and Coakley, Kulasi, and Smith (1998) for surveys of the literature.
} 
These background facts and empirical insights motivate our modeling strategy, which is detailed in the following section, and our calibration choices described in Section 4.

\section{A dynamic, open-economy macroeconomic model}

We construct a dynamic macroeconomic model that allows us to analyze the effects of population aging and of a shift from a pay-as-you-go system to a (partially) funded pension system, induced by the pressure of population aging on public pension budgets. The model is based on a version of the overlapping generations model (Samuelson, 1958; Diamond, 1965) introduced by Auerbach and Kotlikoff (1987, chapter 3). Overlapping generations (OLG) models are well suited to study the effects of population aging on social security systems because they are based on households' and firms' optimal reactions to movements in the demographic structure and public policy measures.

Overlapping generations models have also been used to analyze international capital flows since the seminal contribution by Buiter (1981). More recently, several authors developed large-scale multi-country OLG models to study the effects of population aging and pension reform on international capital flows. While Attanasio and Violante (2000) focus on how the Latin American demographic transition affects international capital markets, Brooks (2003), Feroli (2002), Henriksen (2002) and Domeij and Floden (2005) examine capital flows in multi-regional OLG models.

Our paper improves in several dimensions on the existing literature. The above papers do not model PAYG pension systems and accordingly do not address the important issue of pension reform with its associated changes in saving patterns which in turn have implications on international capital flows. ${ }^{2}$ Issues related to pension reform are also addressed by INGENUE (2001) and Fehr, Jokisch, and Kotlikoff (2003, 2004). We improve on these papers because we use more detailed demographic projections that model the various dimensions of demographic change, and we carefully distinguish between the effects of population aging and population shrinkage. Our work shows that the delicate effects of the differential timing of demographic change across countries on macroeconomic aggregates and capital flows can only be assessed with realistic demographic forecasts; they are largely ignored in the stylized demographic transition schemes used in other work. We explicitly take three single European countries (France, Germany, and Italy) as examples for countries that are differently affected

\footnotetext{
${ }^{2}$ An exception is Domeij and Floden (2004) who model pension systems but do not address pension reforms.
} 
by population aging within Europe. France is aging much less than Germany and Italy. Accordingly, we do not only analyze capital flows from Europe to the rest of the world but also the resulting intra-European capital flows. Furthermore, we account for differences in the generosity of pension systems and simulate the impact of a stylized pension reform in the regions of our model.

An earlier version of the model used in this study was presented by Börsch-Supan, Ludwig, and Winter (2002). We modify and improve our earlier model along several dimensions. First, we extend the focus of our analysis to the entire European Union and no longer focus on Germany (exclusively). Second, we model endogenous labor supply decisions and hence implement important feedback effects due to differences in the relative returns on capital and labor which result from population aging. Third, we follow Abel (2001, 2003), Altig, et al. (2001) and Fehr, Jokisch, and Kotlikoff (2003, 2004) by including adjustment costs to capital in our analysis which allows us to study the time pattern of the price of capital. Fourth, we allow for life-time uncertainty in the household optimization problem, and we explicitly model age-specific productivity. Fifth, we start our calculations with a phase-in period of 150 years in order to relax the contra-factual assumption of a steady state in 2002, the reference year of the simulations we present. This is important for two reasons: it allows us to analyze how our model matches empirical counterparts of long time series of data, especially international capital flows and labor supply. We also avoid distortions due to adjustments of the model towards an equilibrium path which result from the arbitrary imposition of an initial steady state or other initial conditions.

The model has three building blocks: a demographic projection, a stylized pension system, and a macroeconomic overlapping generations model which generates the general equilibrium of the internationally linked economies. Initial values and parameters for these building blocks will be described in Section 4.

\subsection{The demographic projection model}

Detailed demographic projections form the background of our analysis. Demography is taken as exogenous and represents the main driving force of our simulation model. ${ }^{3}$ In each country $i$, the size of population of age $j$ in period $t, N_{t, j, i}$, is given recursively by

\footnotetext{
${ }^{3}$ We are aware that in the long run, neither fertility nor mortality is exogenous to economic growth. Migration reacts to international income differences also in the short-run. The literature, however, has so far not provided
} 


$$
N_{t+1, j+1, i}=N_{t, j, i}\left(s_{t, j, i}+m_{t, j, i}\right) \text { for } j>0 \text { and } N_{t+1,0, i}=\sum_{j=15}^{50} f_{t, j, i} N_{t, j, i}
$$

where $s_{t, j, i}$ denotes the age-specific conditional survival rate, $m_{t, j, i}$ the net migration ratio, and $f_{t, j, i}$ the age-specific fertility rate.

The individuals in our model economies enter economic life at age 20 which we denote by $a=1$. The maximum age as implied by the demographic projections is 104 years. Accordingly the maximum economic age, denoted by $Z$, is 85 . To simplify calculations in our economic model, we assume that all migration takes place at the initial age of 20. This simplifying assumption allows us to treat all "newborns" - immigrants and natives - in our economic model alike. ${ }^{4}$

\subsection{The stylized pension systems}

Each region is assumed to have a two-tier pension system. The first tier represents a conventional public pay-as-you-go (PAYG) system characterized by country-specific contribution and replacement rates. More precisely, for each region $i$, the exogenous policy variable is the time-specific gross replacement rate, $b_{t, i}$, defined as the ratio of average gross pension to average gross wage income at time $t$. The budget of the PAYG pension system is balanced at any time $t$ and determines the contribution rate, $\tau_{t, i}$, by the budget identity

$$
\tau_{t, i} \sum_{a=1}^{Z} w_{t, a, i}^{g} l_{t, a, i} N_{t, a, i}=\sum_{a=1}^{Z} p_{t, a, i}\left(E_{t, i}-l_{t, a, i}\right) N_{t, a, i}
$$

where the pension benefits, $p_{t, a, i}$, are computed as

$$
p_{t, a, i}=b_{t, i} \lambda_{t, a, i} w_{t, a, i}^{g} .
$$

$E_{t, i}$ denotes the time endowment of households which we explain below. On the revenue side, $w_{t, a, i}^{g}$ denotes age-specific gross wages. Net wages are given by $w_{t, a, i}^{n}=w_{t, a, i}^{g}\left(1-\tau_{t, i} / 2\right)$ where half of contributions are paid by the employee and the other half by the employer. This latter half will be taken into account when firms maximize profits. As further specified below, age

robust estimates of the elasticities of demographic movements to economic circumstances suitable for inclusion in this OLG model. This is an important area for further research.

\footnotetext{
${ }^{4}$ Both groups, newborns and immigrants, enter the economic model with zero assets. Furthermore, there are no skill differences between the two groups as analyzed by Razin and Sadka (1999) and Storesletten (2000), among others.
} 
specific gross wages are given by $w_{t, a, i}^{g}=w_{t, i}^{g} \cdot \varepsilon_{a}$, where $\varepsilon_{a}$ is age-specific productivity and $w_{t, i}^{g}$ is the aggregate gross wage resulting from profit maximization, see below. $l_{t, a, i}$ denotes labor supply resulting from optimal household decisions and $l_{t, a, i} N_{t, a, i}$ the number of contributors of age $a$ at time $t$ in country $i$.

On the benefit side of the budget equation, pensions are defined by a product of three terms, the general replacement rate, $b_{t, i}$, aggregate gross wages, $w_{t, i}^{g}$, and "earning points", $\lambda_{t, a, i}$ : for each year of labor force participation, workers are credited points according to their relative earnings. If their annual earnings are equal to the annual average, 1/45 points are credited. If a worker earns $50 \%$ more than the average, $1.5 / 45$ points are credited, etc. Points are summed up over the work history. i.e. to 1 for a 45 year of work history. The recursive representation of $\lambda_{t, a, i}$ is then given by

$$
\lambda_{t+1, a+1, i}=\lambda_{t, a, i}+\frac{1}{45} \frac{\varepsilon_{a} w_{t, i}^{g} l_{t a, i}}{w_{t, i}^{g} \Phi_{t, i}}=\lambda_{t, a, i}+\frac{1}{45} \frac{\varepsilon_{a} l_{t, a, i}}{\Phi_{t, i}}, \quad \text { where } \quad \Phi_{t, i}=\frac{\sum_{a=1}^{Z} \varepsilon_{a} l_{t, a, i} N_{t, a, i}}{\sum_{a=1}^{Z} l_{t, a, i} N_{t, a, i}}
$$

This stylized "point system" is an approximation of the actual benefit formulas in France, Germany, and Italy and takes into account that early retirees only receive a fraction of full pension income. ${ }^{5}$ Benefits are not taxed and we ignore interactions with other social protection systems, such as health insurance. We assume that all persons in each region participate in the same pension system.

The second tier of the stylized pension system represents pre-funded private pensions. ${ }^{6}$ We do not explicitly model this funded component of the pension system. Rather, it consists of voluntary private savings. These savings are determined by households' optimal life-cycle decisions under an intertemporal budget constraint that includes the benefit level of public pensions. Rational forward-looking behavior of households implies that households adjust their voluntary savings in response to variations in the public pension replacement rates induced by demographic change or a pension reform.

\footnotetext{
${ }^{5}$ This comes closest to the French system. Germany actually does not have an upper limit to earnings points, while the new entrants' system in Italy has a notional defined contribution system which gives credits to earnings according to a more complicated formula.

${ }^{6}$ In the language of the World Bank, this second tier corresponds to the "third pillar".
} 
To separate the direct effects of population aging on capital markets and potential feedback effects from pension reform, we present projections for two future hypothetical pension system scenarios which we apply to the three large continental European countries:

(a) Under the "old system scenario", the 2006 replacement rates are maintained throughout the projection period, which, due to population aging, results in rising contribution rates.

(b) Under the "reform scenario", contribution rates are frozen at their 2006 level, which results in decreasing replacement rates. We assume that this pension reform is announced in 2004 and implemented in 2006. This leaves households with an adjustment period of two years prior to implementation of the reform.

These two pension system scenarios are extreme cases. While they are both counterfactual, they help us sharpen the effects of pension reform. The "old system scenario" projects the dominant and monolithic PAYG systems of the 1990s into the future. In fact, however, substantive reform steps are under way in France, Germany, and Italy. In turn, the "reform scenario” introduces faster and deeper transitions to partially funded multi-pillar pension systems than they are currently envisaged in the three countries.

\subsection{The overlapping generations model}

The two core elements of the macroeconomic general equilibrium model are the production and the household sectors.

The production sector in each country consists of a representative firm that uses a CobbDouglas production function given by

$$
Y_{t, i}=F\left(\Omega_{i}, K_{t, i}, L_{t, i}\right)=\Omega_{i} K_{t, i}^{\alpha} L_{t, i}^{1-\alpha},
$$

where $K_{t, i}$ denotes the capital stock and $L_{t, i}$ the labor supply of country $i$ at time $t$. Labor supply, $L_{t, i}$, is measured in efficiency units. $\alpha$ is the capital share.

Production efficiency of a household of age $a$ at time $t$ in country $i$ has a factorial structure with three elements, relating to age, time and country. On the micro level, where households are distinguished by their age, labor productivity changes over the life-cycle according to agespecific productivity parameters $\varepsilon_{a}$. Hence, the age-specific gross wage is $w_{t, a, i}^{g}=w_{t, i}^{g} \cdot \varepsilon_{a}$ and the aggregate labor supply is $L_{t, i}=\sum_{a=1}^{Z} \varepsilon_{a} l_{t, a, i} N_{t, a, i}$ where $l_{t, a, i}$ denotes a single household's labor supply. 
Second, aggregate and individual labor supply $\left(L_{t, i}\right.$ and $\left.l_{t, a, i}\right)$ are measured in efficiency units relative to a time endowment $E_{t, i}$. The actual age-specific labor supply which corresponds to what is observed in the data is therefore given by $L_{t, a, i}^{a c t u a l}=\frac{l_{t, a, i} N_{t, a, i}}{E_{t, i}}$. The time endowment grows at a constant rate, $g$. This "growth in time endowment" specification is equivalent to the standard labor augmenting technological change specification for the production sector and has useful properties for the specification of the household sector, see below.

Third, $\Omega_{i}$ is the technology level of country $i$. We calibrate $\Omega_{i}$ such that aggregate detrended GDP averaged over the calibration period is replicated in each country, see below.

We assume that investment is subject to convex adjustment costs (Hayashi, 1982) with a proportionality factor $\psi$. The dynamic problem of the firm is given by

$$
\max _{\left\{K_{t, i}\right\}_{t=1}^{\infty},\left\{L_{t, i}\right\}_{t=1}^{\infty},\left\{I_{t, i}\right\}_{t=1}^{\infty}} \sum_{t=1}^{\infty} d_{t, i}^{f} F\left(\Omega_{i}, K_{t, i}, L_{t, i}\right)-I_{t, i}-C\left(I_{t, i}, K_{t, i}\right)-w_{t, i}^{g} L_{t, i}\left(1+\tau_{t, i} / 2\right)
$$

subject to

$$
\begin{aligned}
& C\left(I_{t, i}, K_{t, i}\right)=\frac{\psi}{2} \frac{I_{t, i}^{2}}{K_{t, i}} \text { and } \\
& I_{t, i}=K_{t+1, i}-K_{t, i}(1-\delta),
\end{aligned}
$$

where $d_{t, i}^{f}$ is the firm's discount factor defined by $d_{t, i}^{f}=\prod_{s=1}^{t}\left(1+r_{s, i}\right)^{-1}$ and $\delta$ is the rate of depreciation of capital. The adjustment cost formulation in equation (7) is the standard quadratic term, and the term $1 /\left(1+\tau_{t, i} / 2\right)$ in equation (6) reflects the fact that 50 percent of social security contributions are paid by the employer.

The first order conditions resulting from profit maximization give the following expressions for equilibrium wages and interest rates and for the equilibrium price of capital:

$$
\begin{aligned}
& w_{t, i}^{g}=\left(1-\alpha_{i}\right) \frac{1}{1+\tau_{t, i} / 2} \frac{Y_{t, i}}{L_{t, i}}, \\
& q_{t, i}=1+\psi \frac{I_{t, i}}{K_{t, i}}, \text { and }
\end{aligned}
$$




$$
r_{t, i}=\frac{F_{K_{t, i}}+(1-\delta) \Delta q_{t, i}+\frac{\psi}{2}\left(\frac{I_{t, i}}{K_{t, i}}\right)^{2}}{q_{t-1, i}}-\delta,
$$

where $q_{t, i}$ denotes the Lagrangian factor of the net investment equation (8), the total marginal costs of investment, which, in this formulation, also equals Tobin's $q$ (Tobin 1969; Hayashi, 1982). $F_{K}$ denotes the marginal product of capital. Equation (11) is the familiar arbitrage condition for the rate of return on financial and physical investment: The return on financial investment, $r_{t, i}$, must be equal to the return on one unit of physical investment at a price of $q_{t-1, i}$ in each country. The latter equals the marginal product of capital plus capital gains on nondepreciated capital plus the reduction in marginal adjustment costs minus depreciation. If $\psi$ $=0$, i.e. if there are no adjustment costs to capital, then equation (11) reduces to the standard static condition $r_{t, i}=F_{K^{-}} \delta$.

In order to determine aggregate consumption, we next consider optimal household behavior derived from intertemporal utility maximization. By choosing an optimal consumption path, each cohort maximizes at any point in time $t$ and age $a$ the sum of discounted future utility. The within-period utility function exhibits constant relative risk aversion, and preferences are additive and separable over time. The maximization problem of a cohort at $a=1$ is given by

$$
\max _{\left.\left\{C_{t+a-1, a, i}\right\}_{a=1}^{Z}, l_{l+a-1, a, i}\right\}_{a=1}^{Z}} \sum_{a=1}^{Z} \frac{1}{(1+\rho)^{a-1}} \pi_{t, a, i} U\left(C_{t+a-1, a, i}, E_{t+a-1, i}-l_{t+a-1, a, i}\right),
$$

where $\rho$ is the pure time discount rate. In addition to pure discounting, households discount future utility with their unconditional survival probability in period $t, \pi_{t, a, i}=\prod_{j=1}^{a} s_{t+j-1, j, i} . C_{t, a, i}$ denotes consumption and $l_{t, a, i}$ labor supply of the household. Remember that the latter is measured in efficiency units relative to the time endowment $E_{t, i}$. We assume that the period specific utility function is of the standard CES form given by

$$
U\left(C_{t, a, i}, E_{t, i}-l_{t, a, i}\right)=\frac{1}{1-\sigma}\left\{\left(\left[\omega_{a, i} C_{t, a, i}^{-\gamma}+\left(1-\omega_{a, i}\right)\left(E_{t, i}-l_{t, a, i}\right)^{-\gamma}\right]^{-\frac{1}{\gamma}}\right)^{1-\sigma}-1\right\},
$$

where $\sigma$ is the coefficient of relative risk aversion. $\omega_{a, i}$ is the consumption share parameter, i.e. the weight of consumption relative to leisure in the household's utility which varies both across countries and across age. Finally, we denote by $\xi=1 /(1+\gamma)$ the intra-temporal substitution elasticity between consumption and leisure. 
A feature of our model is uncertainty about the time of death expressed in the term $\pi_{t, a, i}$ in equation (13). We assume perfect annuity markets which implies that accidental bequests are distributed implicitly, as in the life-insurance framework by Yaari (1965); see also Rios-Rull (1996, 2001). ${ }^{7}$ We do not include intended bequests in our model.

Denoting total wealth by $A_{t, a, i}$, maximization of the household's intertemporal utility is subject to a dynamic budget constraint given by

$$
A_{t+1, a+1, i}=\frac{1}{s_{t, a, i}}\left(A_{t, a, i}\left(1+r_{t+1, i}\right)+l_{t, a, i} w_{t, a, i}^{n}+\left(E_{t, i}-l_{t, a, i}\right) p_{t, a, i}-C_{t, a, i}\right) .
$$

The term $1 / s_{t, a, i}$ reflects how the accidental bequests are dissipated through the annuity market. Income consists of asset income, net wages, and pensions.

Furthermore, maximization is subject to equation (4) and to the constraint that leisure may not exceed time endowment (and may not be negative),

$$
0 \leq l_{t, a, i} \leq E_{t+a, i}
$$

The solution to the optimization problem is characterized by an inter-temporal equation for the marginal utility of consumption,

$$
\frac{\partial u}{\partial C_{t, a, i}}=\frac{1+r_{t+1, i}}{1+\rho} \frac{\partial u}{\partial C_{t+1, a+1, i}}
$$

and an intra-temporal equation relating the marginal utility of leisure to the marginal utility of consumption,

$$
\frac{\partial u}{\partial E_{t, i}-l_{t, a, i}}=\frac{\partial u}{\partial C_{t, a, i}}\left(w_{t, a, i}^{n}-p_{t, a, i}+\mu_{t, a, i}\right)-s_{t, a, i} \frac{1}{1+\rho} \frac{1}{45} \frac{\varepsilon_{a}}{\Phi_{t, i}} \frac{\partial V_{t+1, a+1, i}}{\partial \lambda_{t+1, a+1, i}},
$$

where $\mu_{c, a, i} \geq 0$ is the shadow value of leisure. The last term reflects the increase in the value function resulting from an additional unit of labor supply. ${ }^{8}$

Ignoring the last term in equation (17) since it is second order and numerically small, we arrive at the following approximate solution of the household problem given by

\footnotetext{
${ }^{7}$ One might object to the counterfactual assumption of perfect annuity markets and the absence of explicitly defined accidental bequests. As we show in a detailed sensitivity analysis, allowing for accidental bequests and using alternative redistribution schemes turns out not to significantly alter our simulation results; see BörschSupan, Ludwig, and Winter (2004).
} 


$$
C_{t+1, a+1, i}=C_{t, a, i}\left(\frac{1+r_{t+1, i}}{1+\rho}\right)^{1 / \sigma}\left(\frac{v_{t+1, a+1, i}}{v_{t, a, i}}\right)^{1 / \sigma}
$$

where $v_{t, a, i}=\left(\omega_{a, i}+\left(1-\omega_{a, i}\right) l c r_{t, a, i}^{-\gamma}\right)^{-\frac{1+\gamma-\sigma}{\gamma}}$. The leisure-consumption ratio, $l c r_{c, a, i}$, is defined by

$$
E_{t, i}-l_{t, a, i}=\left(\frac{1-\omega_{a, i}}{\omega_{a, i}} \frac{1}{w_{t, a, i}+\mu_{t, a, i}-p_{t, a, i}}\right)^{\frac{1}{1+\gamma}} C_{t, a, i}=l c r_{t, a, i} \cdot C_{t, a, i}
$$

In equation (19) and elsewhere, we do not distinguish explicitly between workers and pensioners. Each cohort is represented by a single household who supplies $l_{t, a, i}$ units of labor. As a result of optimal household behavior under the public pension rules defined in Section 3.2, the time endowment spent for active work, $l_{t, a, i}$, decreases over the life-cycle. The representative household thus receives a mix of a net wage $w_{t, a, i}^{n}$ and a public pension $p_{t, a, i}$, where the mix shifts from all wages to all pensions.

As described above, variations in the time endowment, $E_{t, i}$, reflect labor augmenting technological change. In the household sector, households become more efficient in using their entire time, i.e., not only labor but also leisure becomes more efficient. This specification of technological change goes back to Altig et al. (2001) and, as discussed there, permits a flexible choice of the substitution elasticity between consumption and leisure $\xi=1 /(1+\gamma)$.

\subsection{Equilibrium}

We define the dynamic general equilibrium of the model economy sequentially. ${ }^{9}$

Definition 1. The approximate competitive equilibrium of the economy is defined as a sequence of disaggregate variables, $\left\{C_{t, a, i}, l_{t, a, i}, A_{t, a, i}\right\}$, aggregate variables $\left\{C_{t, i}, L_{t, i}, K_{t, i}\right\}$, prices for capital and labor $\left\{q_{t, i}, w_{t, i}\right\}$ in each country $i$, and a common world interest rate $\left\{r_{t}\right\}$ such that

1. The allocations are feasible, i.e.

\footnotetext{
${ }^{8}$ An additional equation of motion recursively describes the evolution of the marginal value of earning points, $\partial V_{t, a, i} / \partial \lambda_{t, a, i}$.
} 
$Y_{t, i}+r_{t} F_{t, i}=S_{t, i}^{n}+C_{t, i}+D_{t, i}=S_{t, i}^{g}+C_{t, i}=$

$\sum_{a=1}^{Z}\left(s_{t, a, i} A_{t+1, a+1, i}-A_{t, a, i}\right) N_{t, a, i}+\sum_{a=1}^{Z} C_{t, a, i} N_{t, a, i}+\left(\delta-(1-\delta) \frac{\Delta q_{t, i}}{q_{t-1, i}}\right) q_{t-1, i} K_{t, i}$

where $F_{t, i}$ is the amount of foreign assets, $D_{t}$ is depreciation of capital valued in units of consumption and accounting for gains on non-depreciated capital and $S_{t, i}^{n}\left(S_{t, i}^{g}\right)$ is net (gross) savings.

2. Factor prices equal their marginal productivities as given in equations (9) through (11).

3. Firms and households behave optimally, i.e., firms maximize profits in equation (6) subject to the constraints in equations (7) and (8) and households maximize life-time utility given by equation (12) subject to the constraints in equations (14) and (15).

4. All markets clear. Market clearing on national markets requires that

$$
S_{t, i}^{n}=\sum_{a=1}^{Z} S_{t, a, i}^{n} N_{t, a, i} \quad C_{t, i}=\sum_{a=1}^{Z} C_{t, a, i} N_{t, a, i} \quad A_{t, i}=\sum_{a=1}^{Z} A_{t, a, i} N_{t, a, i} \quad L_{t, i}=\sum_{a=1}^{Z} l_{t, a, i} N_{t, a, i}
$$

Market clearing on the international capital market and the assumption of perfect capital mobility across regions requires that the rate of return on financial investment is equalized across all countries,

$r_{t, i}=r_{t}$,

and that the sum of all foreign assets across all world regions equals zero, i.e.

$$
\sum_{i=1}^{R} F_{t, i}=0
$$

Hence, in equilibrium world output is equal to

$$
Y_{t}=\sum_{i=1}^{R} Y_{t, i}=\sum_{i=1}^{R}\left(S_{t, i}^{n}+C_{t, i}+D_{t, i}\right)
$$

Foreign assets are defined as the difference between total and home assets that are equal to the value of the home capital stock

\footnotetext{
${ }^{9}$ Our definition of equilibrium as sequential is consistent with our computational method. The equilibrium can be computed numerically since the model economy converges to a steady state and becomes a well-behaved system with a small number of equations.
} 


$$
F_{t, i}=A_{t, i}-H_{t, i}=A_{t, i}-q_{t-1, i} K_{t, i}
$$

and international capital flows are defined by the difference between gross savings and investment

$$
C A_{t, i}=S_{t, i}^{g}-q_{t, i} I_{t, i},
$$

where $q_{t, i} I_{t, i}$ is physical investment valued in terms of consumption units which, in turn, is given by

$$
q_{t, i} I_{t, i}=q_{t, i}\left(K_{t+1, i}-(1-\delta) K_{t, i}\right)=q_{t, i} K_{t+1, i}-q_{t-1, i} K_{t, i}+\left(\delta-(1-\delta) \frac{\Delta q_{t, i}}{q_{t-1, i}}\right) q_{t-1, i} K_{t, i} .
$$

The last term on the right-hand side of equation (21) reflects depreciation net of capital gains. $^{10}$

Finally and for further reference it is useful to define the household saving rate as total savings net of depreciation divided by disposable income from domestic and foreign sources:

$$
s r_{t, i}=\frac{S_{t, i}^{n}}{Y_{t, i}+r_{t} F_{t, i}} .
$$

\subsection{Numerical implementation}

Our time line has four periods: a phase-in period, a calibration period, a projection period, and a phase-out period. First, we start calculations 110 years before the calibration period begins with an initial steady state. The time between 1960 and 2001 is then used as calibration period in order to determine the structural parameters of the model. Our projections run from 2002 through $2100 .^{11}$ The phase-out period after 2100 has two parts: a transition to a steady-state population in 2200 and an additional 100-year period until the model reaches a final steady state in 2300.

We determine the equilibrium path of the overlapping generations model by using a first-order tatonnement iteration (see Auerbach and Kotlikoff, 1987). The algorithm searches for equilib-

\footnotetext{
${ }^{10}$ Throughout these accounting definitions we made use of our simplifying assumption that all migration is concentrated at age $a=1$. Since initial wealth is zero, we therefore do not have to account for transfers of assets due to migration.

${ }^{11}$ Results are displayed through the year 2070 to show the main period of population aging.
} 
rium paths of capital to output ratios and labor supply in each country and is described in detail in Ludwig (2004).

\section{Calibration}

In order to capture projected international differences in demographic change and the generosity of public pension systems, we distinguish seven world regions in the benchmark scenario: (i) France, (ii) Germany, and (iii) Italy as three large European countries severely affected by population aging, (iv) the remainder of the European Union, (v) North America (the US and Canada), (vi) the remaining OECD countries, and (vii) all other countries in the world. While we treat France, Germany, and Italy as separate regions in the simulations, we simplify the presentation of most of our simulation results by aggregating them into a combined FranceGermany-Italy region.

Our demographic model for these regions is calibrated to fit the United Nations (2001) projections. These projections end in 2050. Between 2050 and 2100, we continue the linear increase in life-expectancy assumed by the UN and impose constant fertility rates at the levels reached in 2050. During the phase-out period of the model beyond 2100, demographic processes stabilize such that stable populations are reached at $2200 .^{12}$

In order to solve the pension system equations (1) and (2) for each country, we assume that net replacement rates are constant over time at current levels. We then solve for the associated time paths of the contribution rates. We calibrate the pension systems with data on gross replacement rates taken from Palacios and Pallarès-Miralles (2000) and employee's social security contributions taken from OECD (2001). Finally, we solve for equilibrium contribution rates using the budget constraint in equation (1).

Further parameters of the model are the households' preference parameters, the parameters of the production function, and values of the age-specific productivity profile. For the latter, we use the cohort-corrected non-linear regression estimates by Fitzenberger, et al. (2001). This provides us with a representative age-wage profile that peaks at the age of 52 and then decreases slightly.

\footnotetext{
12 Population data for 1950-2050 are given at an annual frequency for five-year age-groups. Further input data such as age-specific mortality rates, life expectancy, and aggregate migration is only given at quinnquennial frequency. We interpolate between age groups and time intervals and "backfit" our population model to the UN population data for the time period 1950-2050.
} 
With two exceptions, technological and preference parameters are assumed to be constant and equal across all countries. The values of these parameters are standard in the literature and summarized in Table 1. The growth rate of productivity, $g$, is set to 1.5 percentage points which is slightly higher than the value of 1.4 percentage points suggested by Cutler, et al. (1990) and closer to the long-run projections suggested by the OECD. The capital share parameter, $\alpha$, is usually set to a value between 0.3 and 0.4 . We set it to the intermediate value of 0.35 . The annual depreciation rate, $\delta$, is assumed to be 5 percentage points per year.

\section{--- Table 1 goes about here ---}

The adjustment cost parameter, $\psi$, deserves more discussion. In a model without depreciation but with capital taxation, and with a lower growth rate, $g$, of 1 percentage point, the value for $\psi$ equal to 10 as chosen by Altig, et al. (2001) results in a steady state $q$-value of 1.04 . The empirical study by Oliner, et al. (1995) finds an equilibrium $q$-value of 1.13. In our model, with a productivity growth rate of 1.5 percentage points and a depreciation rate of 5 percentage points, the value of $\psi=1.5$ that we choose results in a steady state $q$-value of 1.0975 which is just in between these two values used in the literature. As we show in an extensive sensitivity analysis (Börsch-Supan, Ludwig, and Winter, 2004), while allowing us to study the time path of the price of capital, adjustment costs otherwise do not affect our results much.

The discount rate in all countries, $\rho$, is set to 0.01 which is close to the estimate 0.011 of Hurd (1989). With this choice - and given all the other parameter values - our model produces an average capital to output ratio of about 2.9 for the region "European Union” in the calibration period 1960-2001. While comparable capital-output ratios for a large cross-section of countries are not available, a value of 2.9 is reasonable for many countries (OECD, 2003). The coefficient of relative risk aversion is set to 2 which is within the standard range of 1 and 4 . We follow Altig, et al. (2001) in choosing the value for the intra-temporal substitution elasticity $\xi=1 /(1+\gamma)=0.8$.

Levels of total factor productivity, $\Omega_{i}$, vary across countries and are calibrated such that the model replicates output data in each country for the period $1960-2001 .^{13}$ Consumption share parameters, $\omega_{i, a}$, vary across country and age. We define the functional form of $\omega_{i, a}$ in each country as

\footnotetext{
${ }^{13}$ Since there is no government consumption in our theoretical model, we define output as the difference between actual GDP and government consumption.
} 


$$
\omega_{a, i}=\left\{\begin{array}{cc}
\bar{\omega}_{i} & \forall a \leq A^{l} \\
\bar{\omega}_{i}-\Delta \omega_{i}\left(a-A^{l}\right) & \forall A^{l}<\mathrm{a} \leq A^{h} \\
\underline{\omega}_{i}=\bar{\omega}_{i}-\Delta \omega_{i}\left(A^{h}-A^{l}\right) & \forall a>A^{h}
\end{array},\right.
$$

i.e., the consumption share parameter is assumed to be constant for ages $a \leq A^{l}$, then to decrease linearly until it is constant again for ages $a>A^{h} . A^{l}$ is set to 54 beyond which empirically observed labor supply starts to decrease and $A^{h}$ is set to 80 since labor supply is essentially zero in all countries beyond the age of 80 . While we hold the age boundaries constant across all countries, we calibrate $\bar{w}_{i}$ and $\Delta \omega_{i}$ such that the simulation model approximately replicates both aggregate labor supply as well as labor supply profiles across ages on average in each country for the period 1960-2001. ${ }^{14}$

A final remark concerns the initial values of the model for the year 2002 under the different capital mobility scenarios. Conceptually, it is problematic to simulate a calibrated macroeconomic model under policy scenarios other than the one for which it was calibrated. In our case, the world for which we calibrate the model changes with the number of regions considered in the capital mobility scenarios. On the one hand, it would make sense to adjust the calibration parameters each time we change the number of regions that we consider. On the other hand, this would change households' reactions to changes in policy and it would therefore be more difficult to interpret our results with respect to a reform of the public pension system. For that reason and since we are primarily interested in the reaction of households to demographic change and fundamental pension reform, we keep parameter values constant across all capital mobility scenarios. We calibrate the model under the assumption that the "OECD" capital mobility scenario correctly reflects the "true" world and therefore that all other capital mobility scenarios are "counterfactual” worlds. The reader will note that this procedure results in differences in the values of the simulated variables in 2002, the base year of our simulations.

\section{Simulation results for alternative pension and capital mobility scenarios}

In this section we present our main results: how will demographic change affect key macroeconomic variables? Since speed and extent of demographic change varies across the world

\footnotetext{
${ }^{14}$ As shown in the working paper version of this paper (Börsch-Supan, Ludwig and Winter, 2004), this parsimonious parameterization of the consumption share parameters results in a decent fit of empirically observed labor supply profiles. As further discussed there, the model replicates the broad trends of international capital flows across regions.
} 
regions, we would observe differential impacts of demographic change on rates of return to capital in each region if the regions were closed economies.

In a world of open economies, however, these differences in rates of return will induce international capital flows which will reduce these differentials. In order to illustrate the influence of free capital mobility across regions, we build four capital mobility scenarios from the point of view taken by the three largest economies in continental Europe (France, Germany, and Italy). The first scenario corresponds to a closed economy where all investment of France, Germany, and Italy takes place within these three countries. The other three capital mobility scenarios open this closed economy sequentially up: France, Germany, and Italy diversify their investments (i) across all countries of the European Union, (ii) across all OECD countries, and (iii) across the entire world. The results in Figures 2 through 5 display four lines representing these four capital mobility scenarios. The benchmark scenario assumes that capital mobility is restricted to the OECD area. ${ }^{15}$

In addition to these direct effects of demographic change, there are indirect effects due to the presence of (partially) PAYG financed social security systems. In order to separate the direct effects of population aging on capital markets and potential feedback effects from the existence of pension systems and pension reform, we present our main results for two hypothetical pension policy scenarios described above: (a) the "old system scenario" that maintains these countries' current generous public pension systems, and (b) the "reform scenario" that introduces a transition to a partially funded pension system by freezing contribution rates in these three countries. The other regions' pension systems remain unchanged. By comparing these polar scenarios, we can show that a good portion of the capital market effects of population aging arise even without a fundamental pension reform. Accordingly, the figures below have two panels. Panel (a) corresponds to the "old system scenario", i.e., the direct effects of demographic change, and Panel (b) shows the differences between these two scenarios, i.e., the indirect effects of a fundamental pension reform induced by demographic change.

The interplay between these direct and indirect effects of population aging on macroeconomic variables is complicated because they involve changes in levels and trends. Direct level effects are due to differences in the levels of working-age population ratios across countries.

\footnotetext{
${ }^{15}$ We choose this capital mobility scenario as our benchmark scenario for two reasons. First, as noted in section 2 , there is a broad consensus that capital is quite mobile among OECD countries while this is much less clear for developing countries. Second, adding the additional countries of the region "Rest of the World" does not affect patterns of aggregate variables much because roughly 80 percent of world GDP is produced in the OECD and hence the additional weight of all other world regions is small in relative terms.
} 
Younger economies, i.e. economies with higher working-age population ratios, have higher marginal productivities of capital that will be arbitraged away by international capital flows. Over time, direct trend effects are at work that are related to the speed of demographic change and affect the dynamics of macroeconomic variables: working-age population ratios decrease, capital-output ratios therefore increase and both the rates of return and the savings rates decline.

The indirect effects of PAYG financed pension systems are due to their “crowding out” effect on private savings by providing old-age pension income and their distortionary taxation of labor income. By replacing private savings, the indirect level effect of PAYG financed pension income works in the opposite direction than the direct effect of demographic change. Relative to a situation without PAYG financed pension systems, the indirect effect decreases the differences in saving rates and rates of returns between countries. Over time, old-age dependency ratios increase and therefore contribution rates to the PAYG pension system increase as well (taking PAYG replacement rates as given as we do in the old system scenario). This indirect trend effect is stronger in the older regions that are more severely affected by the impact of demographic change.

In order to illustrate the complicated superimposition of all these direct and indirect level and trend effects, the presentation of our results proceeds in several steps. Throughout, we focus on the economic consequences of aging and of fundamental pension reform on the continental European region consisting of France, Germany, and Italy. As our point of departure, we analyze the impact of the exogenous demographic change on working age population and old-age dependency ratios. We then analyze the two channels of reaction of households to demographic change and fundamental pension reforms by analyzing how labor supply and savings patterns are affected. We next turn to the firm sector and analyze the evolution of wage rates and the return to capital as well as its price, Tobin's $q$. We then focus on the difference between national saving and investment that generates international capital flows and describe how they are affected by demographic change. While our results show substantial differences of international capital flow patterns between countries of the European Union and the other world regions, there are also significant differences between countries within the different world aggregates. To highlight this aspect, we further present results on saving patterns and international capital flows for the three European countries on which we focus (France, Germany, and Italy). We conclude this section with a brief welfare analysis for households living in Germany. 


\subsection{Point of departure: demographic change}

Figure 1 shows the effects of demographic change on two central demographic measures, the share of persons in working age (the number of persons aged 15 to 65 as a percentage of total population) and the old-age dependency ratio (the number of persons older than 65 as a percentage of the working age population).

--- Figure 1 goes about here ---

A number of lessons can be learned from these graphs. First, all world regions are affected by demographic change: the proportions of persons in working age will decrease and the old-age dependency ratios will increase. Second, while the shares of persons in working age have been fairly similar in 2000 for the regions in the OECD, they diverge in the course of population aging. The decrease of the share of persons in working age is strongest for the European Union countries, especially for the three-country group France-Germany-Italy. Third, this country group has also the highest level of the old-age dependency ratio. Fourth, there are significant differences in the timing and the pattern of demographic change across regions. As we will see, these different patterns have profound implications for the evolution of saving rates, rates of return, and international capital flows.

\subsection{Labor supply, contribution and replacement rates}

These demographic changes have immediate effects on labor supply and the balance of the pension system. Labor supply shares in the three European countries France, Germany, and Italy decrease from currently 42 percent to below 36 percent in 2050 . The economic dependency ratio, defined as the ratio of pensioners to workers, is projected to increase from roughly 50 percent in 2002 to about 80 percent in $2050 .^{16}$

As a result of the decrease in labor supply shares and the resulting increase in the economic dependency ratio, the contribution rate to the PAYG pension system increases sharply under the “old system scenario", i.e. if current generous pension systems were maintained. These contribution rates are equilibrium contribution rates such that the budget of the pension system of each country is balanced at every point in time (implicitly including tax subsidies to the pension system). The time patterns of net replacement and contribution rates for France, Germany, and Italy that result from our procedure are summarized in Table 2.

\footnotetext{
${ }^{16}$ The total sum of pensioners ("effective pensioners”) as used in this section is defined as the sum of actual pensioners weighted by their age-specific pension entitlements.
} 
If current generous replacement rates were maintained, our model predicts that the equilibrium contribution rate in Germany would increase from its current level of roughly 27 percent to 41 percent in 2050 - more than a 50 percent increase. The stylized pension reform freezes contribution rates at the level reached in 2006, roughly at 29 percent. As a result of this reform, average pension levels decrease: the net pension replacement rate is projected to decrease from 70 percent in 2000 to about 50 percent in 2050. Hence, for Germany, our model predicts a one-third transition towards pre-funding until 2050. Results for the other countries are similar, compare Table 2.

Households respond to these decreases in pension benefit levels not only by increasing savings, but also by increasing labor supply. ${ }^{17}$ The stylized pension reform would lead to quite substantial increases in aggregate labor supply. Labor supply shares are predicted to increase by more than 6.5 percent or 2.5 percentage points until 2050. This increase is roughly the same for all capital mobility scenarios. For instance, labor supply shares in the FranceGermany-Italy region increase from about 36 percent in the year 2050 under the "old system scenario" to 38.5 percent under the "reform scenario". As a consequence, the economic dependency ratio is projected to decrease by almost 6 percentage points. Endogenous labor supply is therefore a helpful mechanism to dampen the effects of population aging. This effect holds over the entire range of the crucial elasticity parameters in the OLG model (BörschSupan, Ludwig and Winter, 2004).

\subsection{Savings and capital stock}

Panel (a) of Figure 2 shows the aggregate average saving rate of France, Germany, and Italy in the four capital mobility scenarios. In the year 2000, savings rates are substantially higher in the open economy scenarios than in the closed France-Germany-Italy region. This is in line with the higher rates of return realized in an open economy (see next subsection). An open economy diversifies a great deal of the demographic effects (such as a large share of older persons) that create lower saving rates and rates of return.

\section{--- Figure 2 goes about here ---}

This direct level effect is superseded by the demographic changes during the 2000 to 2070 prediction window. Saving rates decrease until 2050 across all capital mobility scenarios since

\footnotetext{
${ }^{17}$ Labour supply is projected to increase also for other parameter constellations, see Section 6.5 below.
} 
the baby boom generation decumulates assets. Saving rates are projected to rebound after the year 2050. The decrease of the savings rate caused by population aging - the difference between the value in 2000 and the minimum reached just after 2040 - is roughly 4.5 percentage points if capital mobility is restricted at most to the EU region (scenarios " $\mathrm{F}+\mathrm{G}+\mathrm{I}$ " and "EU”). If we allow for capital mobility within the OECD or the entire world, this decrease is 6.5 or 8 percentage points, respectively. This larger decrease in the open economy scenarios is explained by the indirect trend effect described above. The diversification advantages of worldwide capital mobility thus decline, and saving rates respond accordingly.

Projected aggregate saving rates under a fundamental pension reform are substantially higher and the effect of a pension reform is stronger in the OECD / World open-economy scenarios (the saving rate is projected to increase by slightly more than one percentage point in the EU scenario as compared to 2 percentage points in the OECD / World scenarios). An increase in national savings leads to an increase in the capital stock and thereby to a decrease in the rate of return to capital, which then crowds out further savings. In those scenarios with a larger international capital market, substantially more savings is generated since - as we show below the rate of return decreases by much less. These projections show that optimal life-cycle behavior generates additional saving under a fundamental pension reform - in our model, it is not the case that additional retirement saving induced by a pension reform crowds out other saving totally, as has often been claimed.

We also accumulate aggregate savings to obtain the world region's asset holdings and capital stocks and the related capital-to-output ratios (figures not shown). As a consequence of decreasing labor supply, the capital-to-output ratio increases from its current level of about 3 until it reaches a level of about 3.25 around 2040 and then decreases slightly when baby boomers decumulate assets (capital mobility scenario “OECD”). This decrease is much more pronounced if we restrict the international capital market to the EU area only. The simultaneous fundamental pension reform of France, Germany, and Italy leads to substantial increases in the capital-to-output ratio if we restrict capital mobility to these countries or the EU area. The increase is much lower if we relax this constraint which suggests that the additional savings shown in Figure 2 are largely invested abroad.

\subsection{The rate of return and the price of capital}

Much of the political and academic debate on the capital market consequences of demographic change and of pension reforms has focused on the rate of return to capital to which we 
turn next. First, we observe the same level effects as already described in the previous section. It is noteworthy that the demographic effect is larger than a second level effect. Since the PAYG systems are slimmer in the aggregate rest-of-the-world region than in France, Germany, and Italy, the capital stock accumulated for retirement savings is larger which depresses rates of return.

Second, as a consequence of population aging and the resulting increase in capital-to-output ratios, our model predicts the rate of return of return to capital to decrease by a bit less than one percentage point if capital moves freely within the OECD, see Figure 3. This decrease is less than would be associated with a "meltdown of asset prices". Third, while the rate of return decreases across all capital mobility scenarios, substantial gains would be possible by shifting investments to 'younger' countries since our model predicts higher returns if we allow for free capital mobility across all world regions. However, as demographic processes are highly correlated across countries (compare Figure 1), differences in demographic processes across countries more or less only affect the level of the rate of return. Furthermore, diversification advantages decrease over time since the above mentioned indirect trend effects are at work as well.

--- Figure 3 goes about here ---

As Panel (b) of Figure 3 suggests, there would be an additional decrease in the rate of return to capital if France, Germany, and Italy simultaneously reformed their pension systems in a fundamental way. This decrease would amount to about 0.25 percentage points until 2070 if capital was freely mobile within these countries only. Due to the increase in labor supply, this long-run decrease in the rate of return is lower than a model with exogenous labor supply would suggest, see Section 6. In contrast to a model of exogenous labor supply, the present model even predicts an increase in the rate of return until about 2030 or 2040 (as a result of the endogenous labor supply reaction). While saving rates immediately start to increase after the reform, labor supply increases as well. As a net effect, this initially leads to a decrease in the capital to output ratio and an associated initial increase in the rate of return to capital. Moreover, and in line with our earlier results in Börsch-Supan, Ludwig and Winter (2002), the decrease in the rate of return is negligibly small if capital moves freely across OECD countries (or the entire world).

Tobin's $q$, the price of capital, also decreases as a consequence of population aging but its level is higher in the demographically younger regions. Results on Tobin's $q$ for the FranceGermany-Italy region are depicted in Figure 5. Notice that the relative decrease of $q$-values is 
lower under the pure PAYG scenario if the capital mobility region is broadened (Panel a). As a consequence of fundamental pension reforms, $q$-values are predicted to increase slightly since the investment to capital ratio increases (Panel b). The long-run effect is stronger if capital mobility is restricted to a smaller region.

--- Figure 4 goes about here ---

\subsection{International capital flows}

International capital outflows from France, Germany, and Italy to other OECD countries roughly follow the pattern of savings and decrease steadily until 2050, see Figure 5. In the OECD and World capital mobility scenarios, they are initially positive at about 2 and 3.2 percentage points and turn negative to -2 and -2.5 percentage points in 2050, respectively; see Figure 5(a). Hence, the model predicts reversals in current account positions for fast aging countries such as France, Germany, and Italy.

--- Figure 5 goes about here ---

So far, our analysis concentrated on France, Germany, and Italy as a country aggregate. However, there are substantial differences across countries, even within continental Europe. To highlight this aspect, we next analyze savings patterns and international capital flows within the region of EU countries under the assumption that the international capital market is restricted to the OECD area.

Figure 6(a) shows saving rates for France, Germany, and Italy, the remaining EU countries and the EU average. The time pattern of German saving rates roughly equals the EU average. Germany's saving rate is projected to decrease from current levels of 7 percent to about 2 percent in 2050. In France, as the demographically youngest among the three regions, decreases in savings rate only last until 2030 and the overall decrease is smaller than in other EU countries. Italy, faced with the strongest population aging process within Europe, is at the other extreme: Italian household's saving rates are projected to become substantially negative in 2050.

$$
\text { --- Figure } 6 \text { goes about here --- }
$$

\subsection{Welfare analysis}

Figure 7 shows the effects of the fundamental pension reform on remaining lifetime utility for different cohorts. We follow Altig et al. (2001) and measure the change in remaining lifetime utility as the equivalent variation of full lifetime income. The index measures the present 
value of remaining life-time resources relative to current full life-time resources a household would have to receive (pay) under the new system to make him indifferent between the old and the new system. Therefore, an index number greater (smaller) than one has to be interpreted as loss (gain) in remaining life-time utility.

--- Figure 7 goes about here ---

The results show that remaining life-time utility of a large number of generations decreases as a consequence of the fundamental pension reform. Cohorts born between the years 1928 and 1982 are those who experience losses in remaining lifetime utility. Welfare losses are slightly higher if we restrict capital to be mobile only within the EU. While substantial welfare gains are possible in the long run in all capital mobility scenarios, the figure also illustrates that fewer cohorts experience losses if the capital mobility regions is widened. However, the difference between the capital mobility scenarios is not large.

\section{Sensitivity analysis}

One of the weaknesses of computational general equilibrium analysis is the dependence of the results on modeling strategies and parameter values. The usual response is an extensive sensitivity analysis. The existing literature has mostly concentrated on sensitivity analysis of simulation results with regard to values of structural (deep) model parameters, see, e.g., Altig, et al. (2002). We provide such "standard" sensitivity analysis in a longer version of this paper (Börsch-Supan, Ludwig, and Winter 2004). This sensitivity analysis shows that results change very little when we vary the main elasticity parameters in their usual ranges. Our politically probably most contentious conclusion, the absence of a serious asset market meltdown, is robust with respect to the choice of these elasticity parameters.

In addition to this conventional sensitivity analysis, we also investigate the robustness of our results with respect to four key dimensions of our model specification: What difference does it make whether labor supply is endogenous or exogenous? Whether investment incurs adjustment costs? Whether perfect annuity markets absorb all accidental bequests? Whether part of retirement income is provided by a PAYG pension system? We find that the first dimension whether labor supply is endogenous - matters a lot for assessing the effects of a pension reform, while the other three dimensions - adjustment costs, annuity markets, and accidental bequests - matter very little (see Börsch-Supan, Ludwig and Winter, 2004).

In the sequel, we therefore only report on the role of endogenous labor supply. For simplicity, we ignore adjustment costs to capital and concentrate on a three-region rather than a seven- 
region model as in the previous section, summarizing the world regions to (i) France, Germany, and Italy, (ii) all other EU countries, and (iii) all other OECD countries. We focus on the differential effects between the old system and the reform scenario because this is were the endogeneity of labor supply matters most.

Figure 8 compares these effects on the saving rate and the rate of return generated by models with endogenous and exogenous labor supply. In the exogenous labor supply specification, we hold age-specific labor supply shares constant at levels obtained in the endogenous labor supply scenario in the year 2000. We first show the reaction of savings to the fundamental pension reform. As depicted in Figure 8(a), the increase of the saving rate is much larger if labor supply is exogenous. Unlike to the case of endogenous labor supply, households cannot simultaneously adjust their labor supply and their saving behavior to the change in policy. They can only react by decreasing consumption such that the saving rate immediately jumps to a higher level after the announcement of the reform.

This difference in behavior directly translates into substantial differences in the time paths of the rate of return to capital, depicted in Figure 8(b). If labor supply is endogenous, the rate of return initially increases since households increase their labor supply as a reaction to the change in policy. This effect is absent when labor supply is exogenous. Hence, the rate of return to capital immediately decreases. As a result, the overall decrease of the rate of return to capital is much larger.

--- Figure 8 goes about here ---

The size of this endogenous labor supply effect of course depends on the elasticity of substitution between consumption and leisure, $\xi$. This is shown in Figure 9, where we vary $\xi$ by \pm 0.2 around its benchmark value of 0.8 and re-calibrate $\bar{w}$, the consumption share parameter, such that initial labor supply shares are held constant. We thereby focus on the case where capital mobility is restricted to the France-Germany-Italy region. We choose this case because it exhibits the strongest sensitivity, see Figure 8. In this "closed economy" case, the increase of labor supply resulting from the fundamental pension reform is only slightly higher if $\xi=1$ (Cobb-Douglas utility), but quite significantly lower if $\xi=0.6$. As a result, the decrease in the rate of return to capital is much stronger for $\xi=0.6$ than for the benchmark calibration of $\xi=0.8$.

--- Figure 9 goes about here --- 


\section{Conclusions}

We presented a quantitative analysis of the effects of population aging and pension reform on international capital markets, using several modifications of a computational general equilibrium multi-country overlapping generations model. Our analysis took the perspective of the three large continental European countries with large pay-as-you-go pensions systems: France, Germany, and Italy.

Population aging works through various mechanisms. First, demographic change alters the time path of aggregate savings within each country. Second, this process may be amplified when a pension reform, induced by the demographic change, shifts old-age provision from pure pay-as-you-go towards more pre-funding. Third, while the patterns of population aging are similar in most countries, timing and initial conditions differ substantially. Hence, to the extent that capital is internationally mobile, population aging will induce capital flows between countries.

All three effects influence the rate of return to capital and interact with the demand for capital in production and with labor supply. Our simulations predict substantial capital flows due to population aging. Population aging results in decreases of the capital-to-output ratio when the baby boomers decumulate their assets. International capital flows follow this trend. The countries most affected by aging such as the European Union will initially be capital exporters, while countries less affected by aging like the United States und other OECD regions will import capital. This pattern is reversed in about the year 2020 when baby boomers decumulate assets and the fast-aging economies therefore become capital import regions. Pension reforms with higher degrees of pre-funding are likely to induce more capital exports. They also increase labor supply considerably, while the effects on the rate of return to capital are small. While the rate of return to capital declines in response to population aging, there is no devastating “asset market meltdown”.

The timing of these adjustment processes is complex, and one has to carefully distinguish level effects from changes over time. In the initial year of our projections (2002), savings rates in the France-Germany-Italy region are substantially higher in the open economy scenarios than under a closed-economy assumption. This is in line with higher rates of return in economies with a smaller share of older persons. Open economies are able to diversify a great deal of the demographic effects that depress savings and the rate of return to capital. 
This level effect is superseded by the demographic changes during the 2002 to 2070 prediction window. Saving rates decrease until 2050 across all capital mobility scenarios since the baby boom generation decumulates assets. Saving rates are projected to rebound after the year 2050. Since PAYG pension systems partially crowd out private savings, decreases of saving rates are stronger in the older regions. As a result, the decrease in the rate of return would be lower in these regions than in regions with less generous pension systems if these regions were closed economies. Diversification advantages of worldwide capital mobility thus decline, and saving rates respond accordingly. We should stress that population projections are reliable one generation ahead, while the projection error increases substantially thereafter. Consequently, results for the post-2030 period should be interpreted with care.

Finally, our paper shows the importance of the interplay between saving and labor supply adjustments in response to population ageing. Saving rates, rates of return and international capital flows react substantially less to demographic change once households absorb some part of the demographic shock by working more. 


\section{References}

Abel, A.B. (2001): Will bequests attenuate the predicted meltdown in stock prices when baby boomers retire? Review of Economics and Statistics, 83(4), 589-595.

Abel, A.B. (2003): The Effects of a Baby Boom on Stock Prices and Capital Accumulation in the Presence of Social Security, Econometrica, 71, 2, 551-578.

Altig, D., A.J. Auerbach, L.J. Kotlikoff, K.A. Smetters, and J. Walliser (2001): Simulating fundamental tax reform in the United States. American Economic Review, 91, 574595.

Ando, A. and F. Modigliani (1963): The 'life-cycle' hypothesis of saving: Aggregate implications and tests. American Economic Review, 89(3), 605-618.

Attanasio, O.P. and G.L. Violante (2000): The demographic transition in closed and open economy: A tale of two regions. Working Paper 412, Research Department, InterAmerican Development Bank, Washington, D.C.

Auerbach, A.J. and L.J. Kotlikoff (1987): Dynamic Fiscal Policy. Cambridge, MA: Cambridge University Press.

Baxter, M. and M. Crucini (1993): Explaining saving-investment correlations. American Economic Review, 83 (3), 416-436.

Bloom, D.E. and J.G. Williamson (1998): Demographic transitions and economic miracles in emerging Asia. World Bank Economic Review, 12(3), 419-455.

Börsch-Supan, A., J. Köke, and J. Winter (2004): Pension reform, savings behavior, and capital market performance. Journal of Pension Economics and Finance, forthcoming.

Börsch-Supan, A., A. Ludwig, and J. Winter (2002): Aging, pension reform, and capital flows. In: A. Auerbach and H. Hermann (eds.), Aging, Financial Markets and Monetary Policy. Heidelberg: Springer, 55-83.

Börsch-Supan, A., A. Ludwig, and J. Winter (2004): Aging, Pension Reform, and Capital Flows: A Multi-Country Simulation Model, Discussion Paper 04-64, MEA, University of Mannheim.

Brooks, R. (2002): Asset-market effects of the baby boom and social-security reform. American Economic Review, Papers and Proceedings, 92(2), 402-406.

Brooks, R. (2003): Population aging and global capital flows in a parallel universe. Working Paper No. 00/151, International Monetary Fund, Washington, D.C. Forthcoming in: IMF Staff Papers.

Buiter, W.H. (1981): Time preference and international lending and borrowing in an overlapping-generations model. Journal of Political Economy, 89(4), 769-797.

Coakley, J., F. Kulasi, and R. Smith (1998): The Feldstein-Horioka puzzle and capital mobility: A review. International Journal of Finance and Economics, 3(2), 169-188

Cutler, D.M., J.M. Poterba, L.M. Sheiner, and L.H. Summers (1990): An aging society: Opportunity or challenge? Brookings Papers on Economic Activity, No. 1, 1-73.

Deardorff, A.V. (1985): Trade and capital mobility in a world of diverging populations. In: D.G. Johnson and R.D. Lee (eds.), Population Growth and Economic Development: Issues and Evidence. Madison, WI: University of Wisconsin Press.

Diamond, P.A. (1965): National debt in a neoclassical growth model. American Economic Review, 55, 1126-1150. 
Domeij, D. and M. Floden (2005): Population aging and international capital flows. International Economic Review, forthcoming.

Fehr, H., S. Jokisch, and L. Kotlikoff (2003): The developed world's demographic transition: The roles of capital flows, immigration, and policy. Working Paper No. 10096, National Bureau of Economic Research (NBER).

Fehr, H., S. Jokisch, and L. Kotlikoff (2004): The role of immigration in dealing with the developed world's demographic transition. Working Paper No. 10512, National Bureau of Economic Research (NBER).

Feroli, M. (2002): Capital flows among the G-7 Nations: a demographic perspective. Unpublished manuscript, New York University.

Feldstein, M. and C. Horioka (1980): Domestic saving and international capital flows. Economic Journal, 90, 314-329.

Fitzenberger, B., R. Hujer, T.E. MaCurdy, and R. Schnabel (2001): Testing for uniform wage trends in West-Germany: A cohort analysis using quantile regressions for censored data. Empirical Economics, 26, 41-86.

French, K.R. and J.M. Poterba (1991): Investor diversification and international equity markets. American Economic Review, Papers and Proceedings, 81(2), 222-226.

Hayashi, F. (1982): Tobin's marginal q and average q: A neoclassical interpretation. Econometrica, 50, 213-224.

Henriksen, E. R. (2002): A demographic explanation of U.S. and Japanese current account behavior. Unpublished manuscript, Carnegie Mellon University.

Higgins, M. (1998): Demography, national savings, and international capital flows. International Economic Review, 39, 343-369.

Hurd, M. (1989): Mortality risk and bequests. Econometrica, 57, 173-209.

INGENUE (2001): Macroeconomic consequences of pension reforms in Europe: An investigation with the INGENUE world model. Working Paper No. 2001-16, CEPREMAP, Paris.

Lucas, R. E. (1988): On the mechanics of economic development. Journal of Monetary Economics, 22, 3-42.

Ludwig, A. (2004): Improving tatonnement methods for solving heterogeneous agent models. Unpublished manuscript, MEA, University of Mannheim.

Lührmann, M. (2003): Demographic change, foresight and international capital flows. Discussion Paper 38-03, MEA, University of Mannheim.

Modigliani, F. and R. Brumberg (1954): Utility analysis and the consumption function: An interpretation of cross-section data. In K.K. Kurihara (ed.): Post-Keynesian Economics. New Brunswick: Rutgers University Press, 388-436.

Obstfeld, M. (1986): Capital mobility in the world economy: Theory and measurement. Carnegie-Rochester Series on Public Policy, 24.

Obstfeld, M. and K. Rogoff (1996): Foundations of international macroeconomics, MIT Press, Cambridge, MA.

Obstfeld, M. and K. Rogoff (2000): The six major puzzles in international macroeconomics: Is there a common cause? NBER Macroeconomics Annual, 15, 339-390.

OECD (2001): Taxing Wages 2000-2001. Paris: OECD.

OECD (2003). STAN database. Paris: OECD. 
Oliner, S., G. Rudebusch, and D. Sichel (1995): New and old models of business investment: A comparison of forecasting performance. Journal of Money, Credit and Banking, 27 (3), 806-826.

Pemberton, J. (1999): Social security: National policies with international implications. Economic Journal, 109, 492-508.

Pemberton, J. (2000): National and international privatization of pensions. European Economic Review, 44, 1873-1896.

Palacios, R. and M. Pallarès-Miralles (2000): International patterns of pension provision. Social Protection Discussion Paper Series No. 0009, The World Bank, Washington, D.C.

Portes, R. and H. Rey (2005): The determinants of cross-border equity flows. Journal of International Economics, 65 (2), 269-296.

Poterba, J.M. (2001): Demographic structure and assets returns. Review of Economics and Statistics, 83(4), 565-584.

Razin, A. and E. Sadka (1999): Migration and pension with international capital mobility. Journal of Public Economics, 74, 141-150.

Reisen, H. (2000): Pensions, Savings and Capital Flows: From Aging to Emerging Markets. Cheltenham, UK: Edward Elgar.

Rios-Rull, J.-V. (1996): Life-cycle economies and aggregate fluctuations. Review of Economic Studies, 63(3), 465-489.

Rios-Rull, J.-V. (2001): Population changes and capital accumulation: The aging of the baby boom. Advances in Macroeconomics, 1(1), Article 7.

Samuelson, P.A. (1958): An exact consumption-loan model of interest with or without social contrivance of money. Journal of Political Economy, 66, 467-482.

Storesletten, K., C. (2000): Sustaining fiscal policy through immigration. Journal of Political Economy, 108, 300-323.

Taylor, A.M. (1994): Domestic saving and international capital flows reconsidered. Working Paper No. 4892, National Bureau of Economic Research (NBER).

Tobin, J. (1969): A general equilibrium approach to monetary theory. Journal of Money, Credit and Banking, 1, 15-29.

United Nations Population Division (2001): World Population Prospects: The 2000 Revision. New York: United Nations.

World Bank (2003): World Development Indicators, The World Bank, Washington, D.C..

Yaari, M.E. (1965): Uncertain lifetime, life insurance, and the theory of the consumer. Review of Economic Studies, 32(2), 137-150. 
Figure 1: Projections of working age population and old-age population ratios for different world regions

Figure 1a: Working-age population ratios

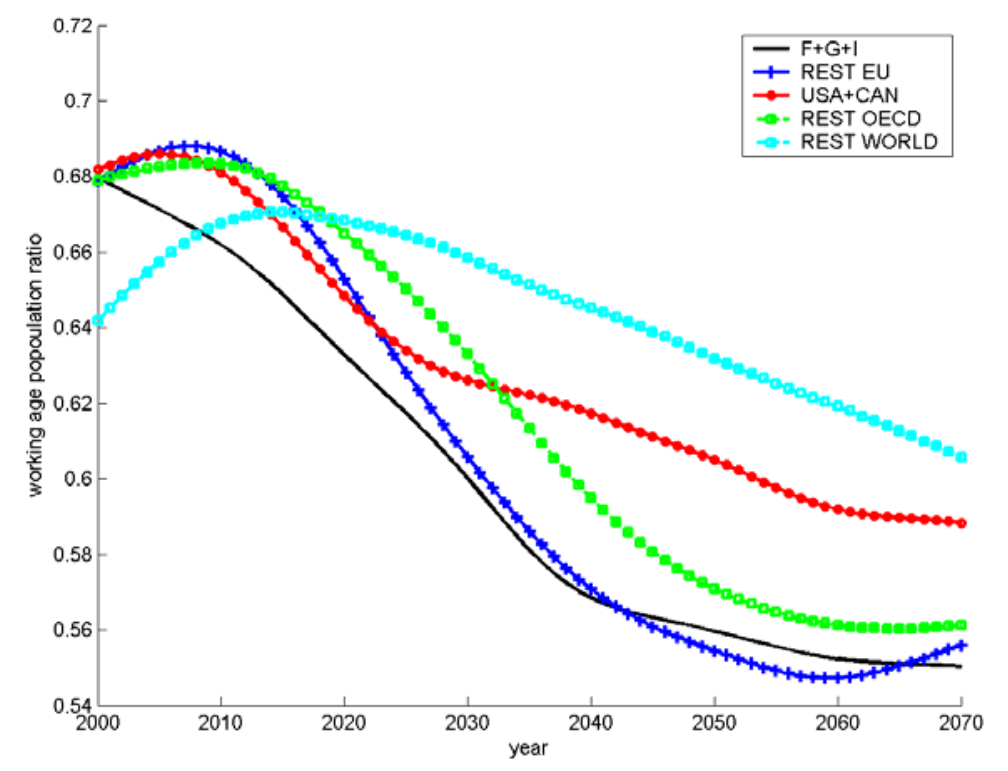

Figure 1b: Old-age dependency ratios

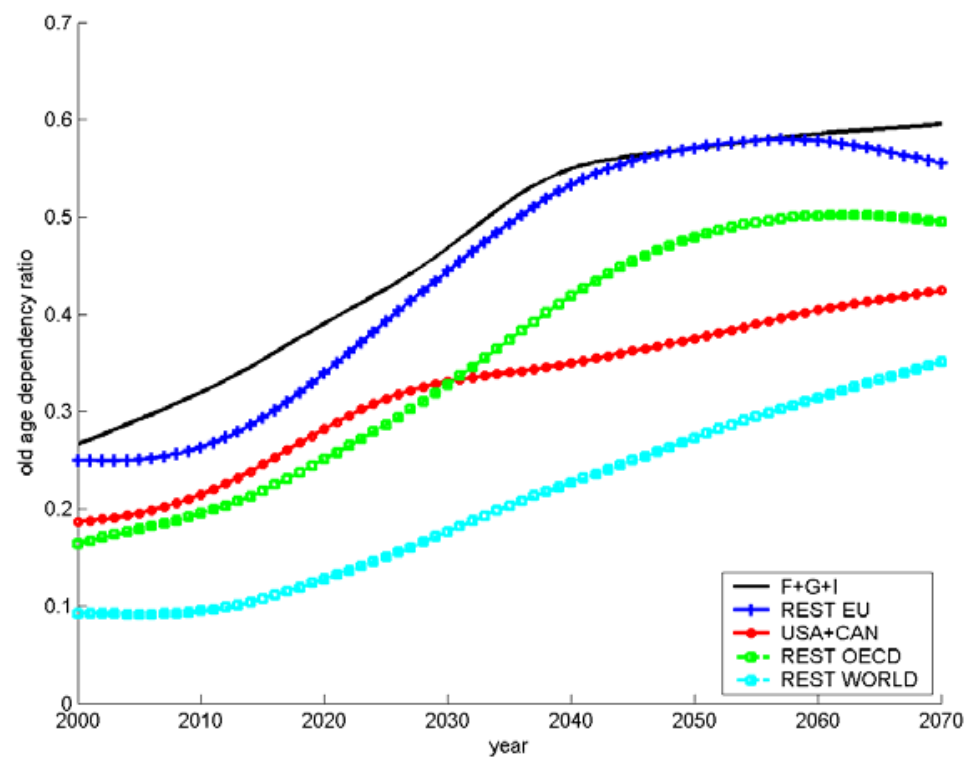

Notes: These figures show projections of the working-age population ratio (the number of people aged 15 to 65 as a percentage of total population) and the old-age dependency ratio (the number of people older than 65 as a percentage of the working age population) for five different world regions. F+G+I: France, Germany, and Italy; REST EU: the remaining countries of the European Union; USA+CAN: the United States and Canada; REST OECD: the remaining OECD countries; REST WORLD: the remaining world countries.

Source: Own calculations, based on demographic projections of the United Nations (2002). 
Figure 2: Saving rates

Figure 2a: Old system scenario

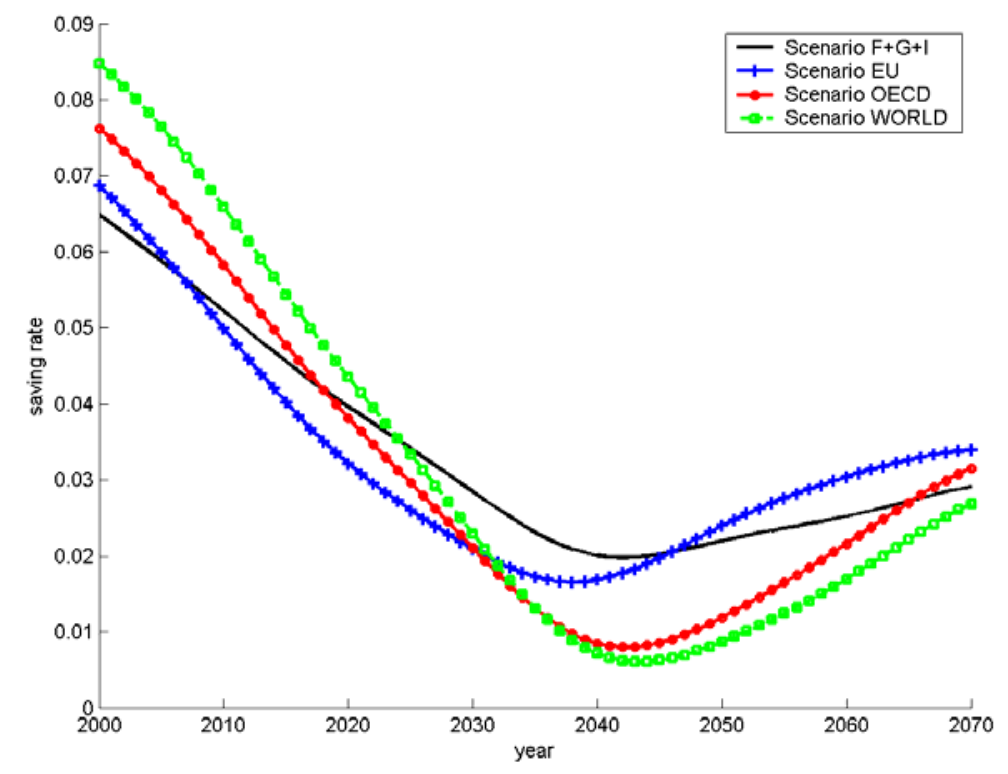

Figure 2b: Difference between reform and old system scenario

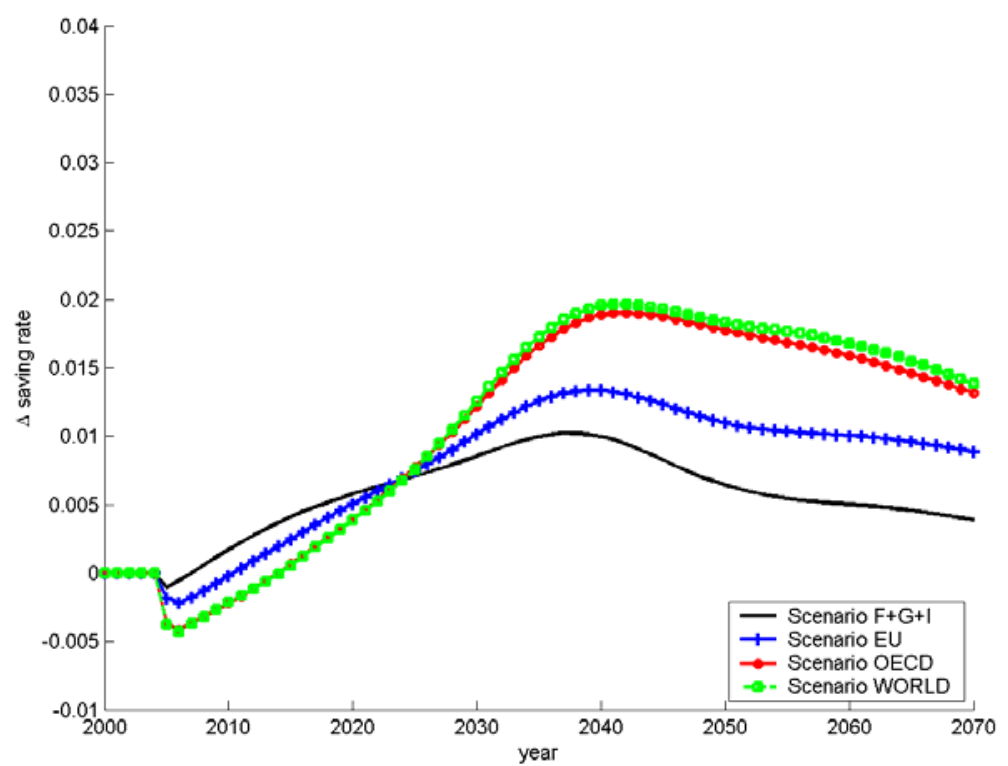

Notes: These figures show the projected aggregate saving rate of households living in France, Germany, and Italy. Scenario F+G+I: perfect capital mobility within France, Germany, and Italy; Scenario EU: perfect capital mobility within the European Union; Scenario OECD: perfect capital mobility with the OECD; Scenario WORLD: perfect capital mobility across all world regions.

Source: United Nations (2002), World Bank (2003), own calculations. 
Figure 3: Rate of return

Figure 3a: Old system scenario

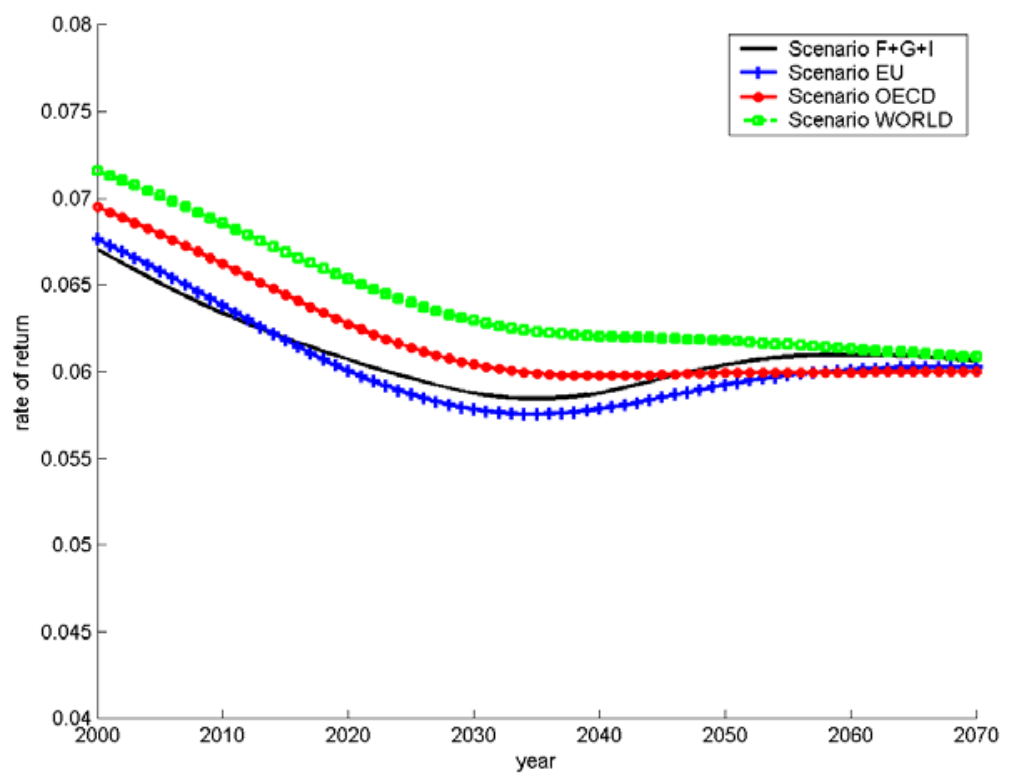

Figure 3b: Difference between reform and old system scenario

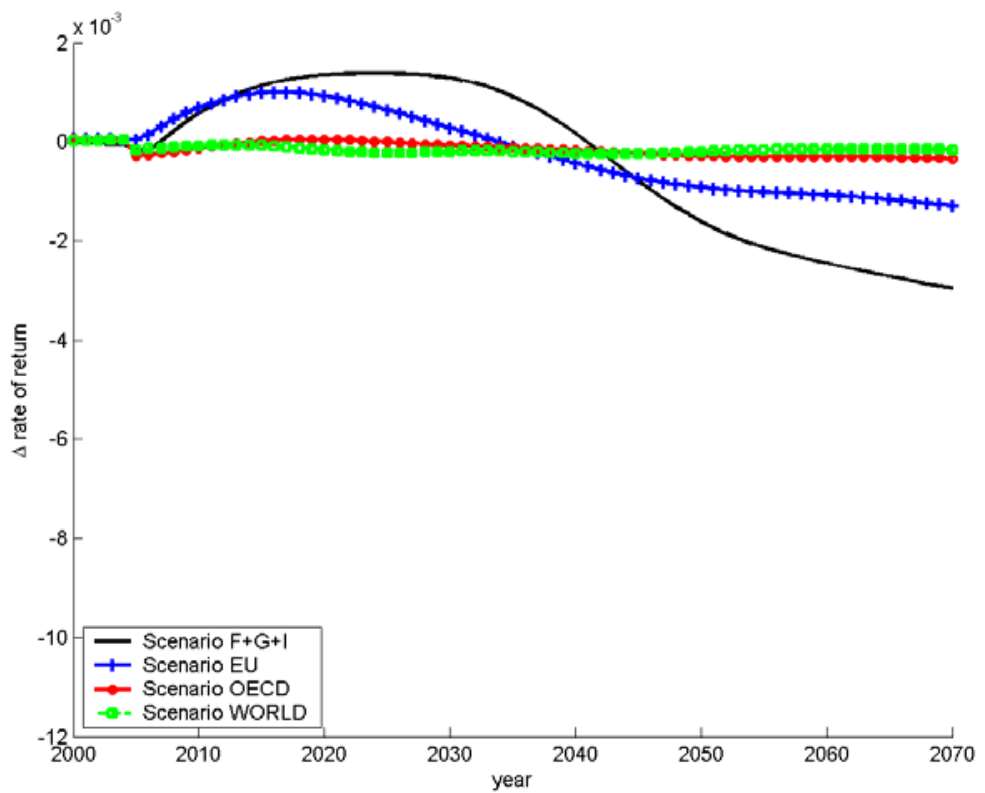

Notes: These figures show the projected rate of return of the aggregate capital stock in France, Germany, and Italy. Scenario F+G+I: perfect capital mobility within France, Germany, and Italy; Scenario EU: perfect capital mobility within the European Union; Scenario OECD: perfect capital mobility with the OECD; Scenario WORLD: perfect capital mobility across all world regions.

Source: United Nations (2002), World Bank (2003), own calculations. 
Figure 4: Tobin's $q$

Figure 4a: Old system scenario

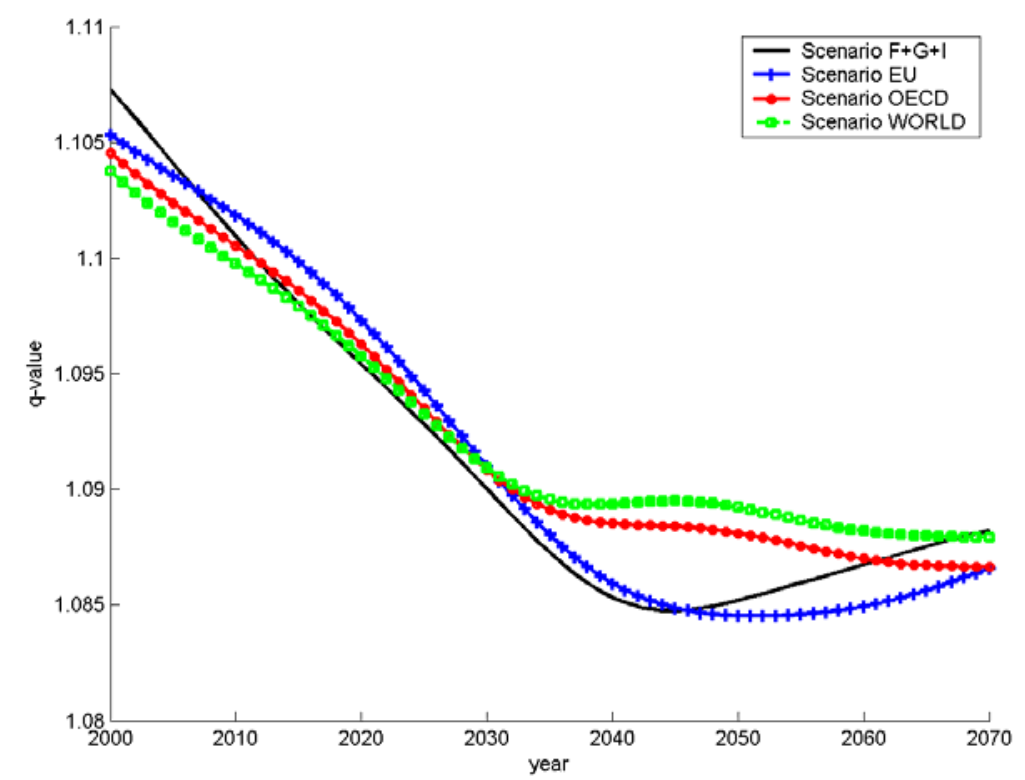

Figure 4b: Difference between reform and old system scenario

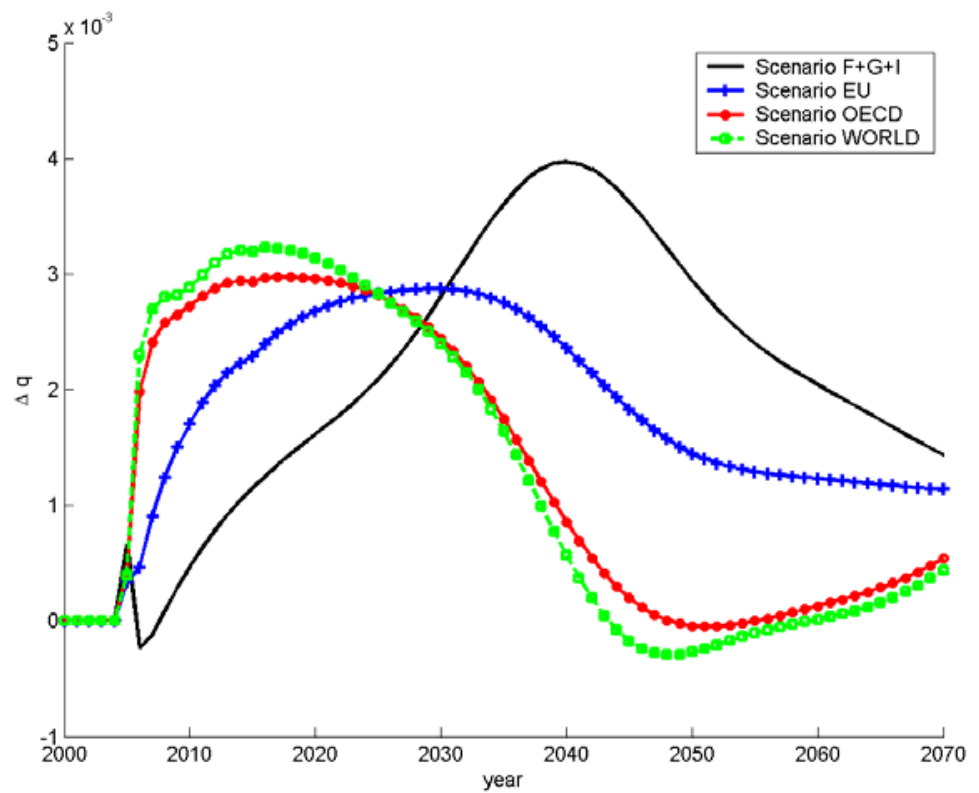

Notes: These figures show the projected $q$-values in France, Germany, and Italy. Scenario F+G+I: perfect capital mobility within France, Germany, and Italy; Scenario EU: perfect capital mobility within the European Union; Scenario OECD: perfect capital mobility with the OECD; Scenario WORLD: perfect capital mobility across all world regions.

Source: United Nations (2002), World Bank (2003), own calculations. 
Figure 5: Current account to output ratios

Figure 5a: Old system scenario

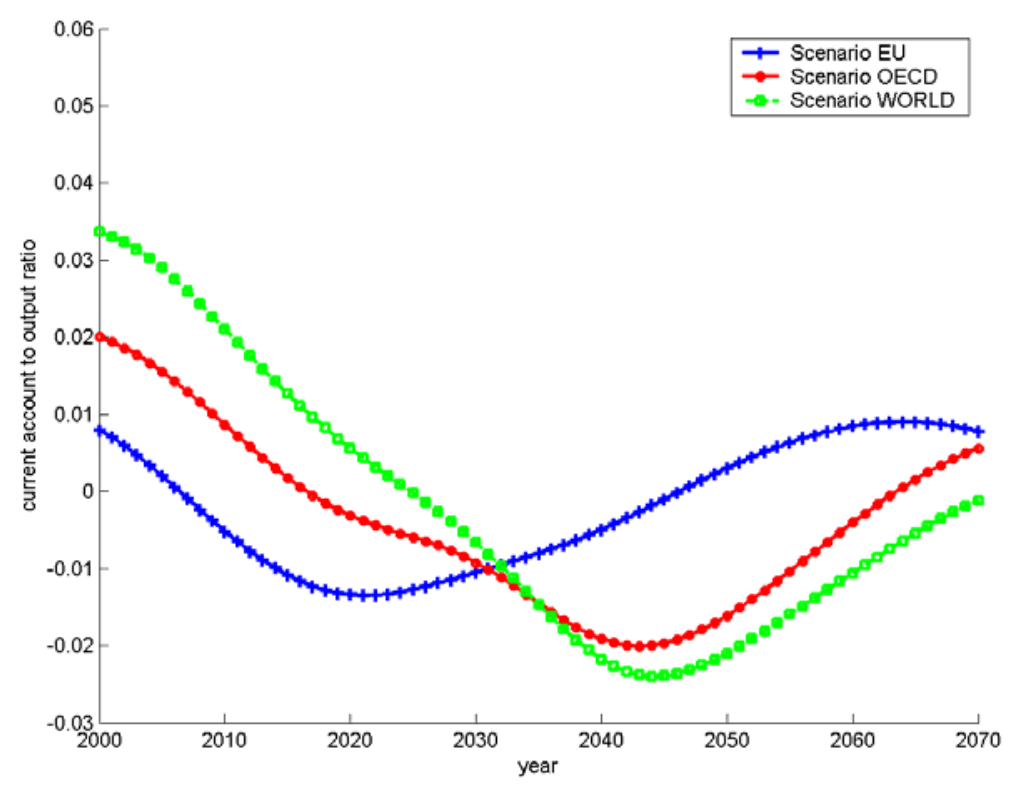

Figure 5b: Difference between reform and old system scenario

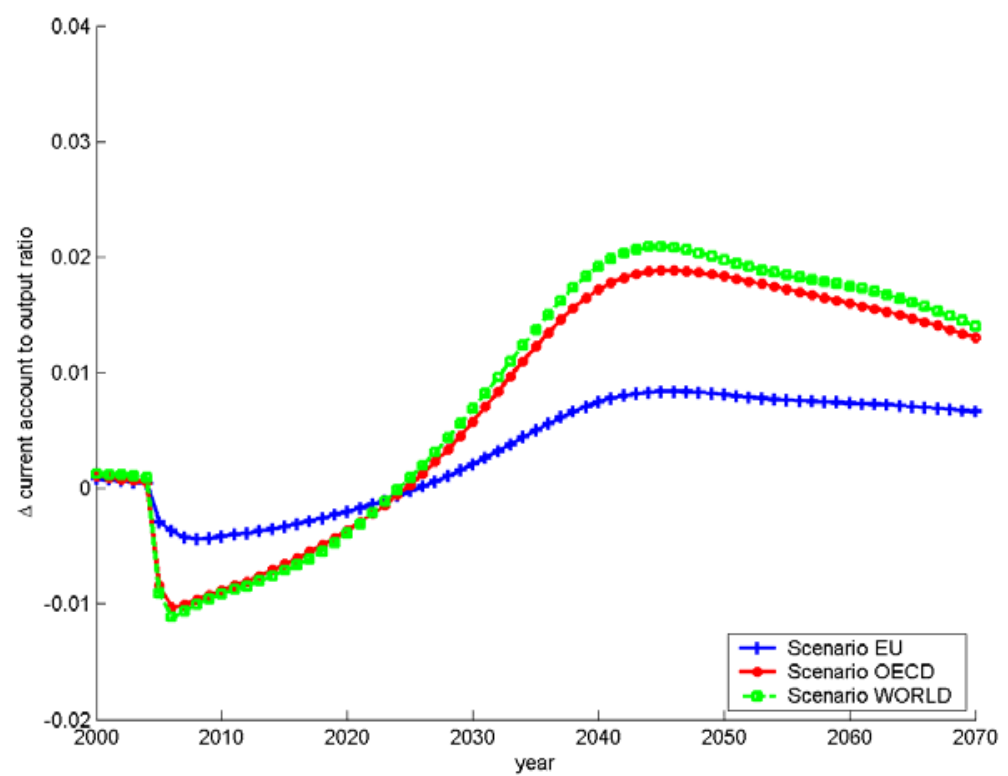

Notes: These figures show the projected current account to output ratio in France, Germany, and Italy. Scenario EU: perfect capital mobility within the European Union; Scenario OECD: perfect capital mobility within the OECD; Scenario WORLD: perfect capital mobility across all world regions.

Source: United Nations (2002), World Bank (2003), own calculations. 
Figure 6: Saving rates and capital flows in the European Union for the OECD scenario

Figure 6a: Saving rate (old system scenario)

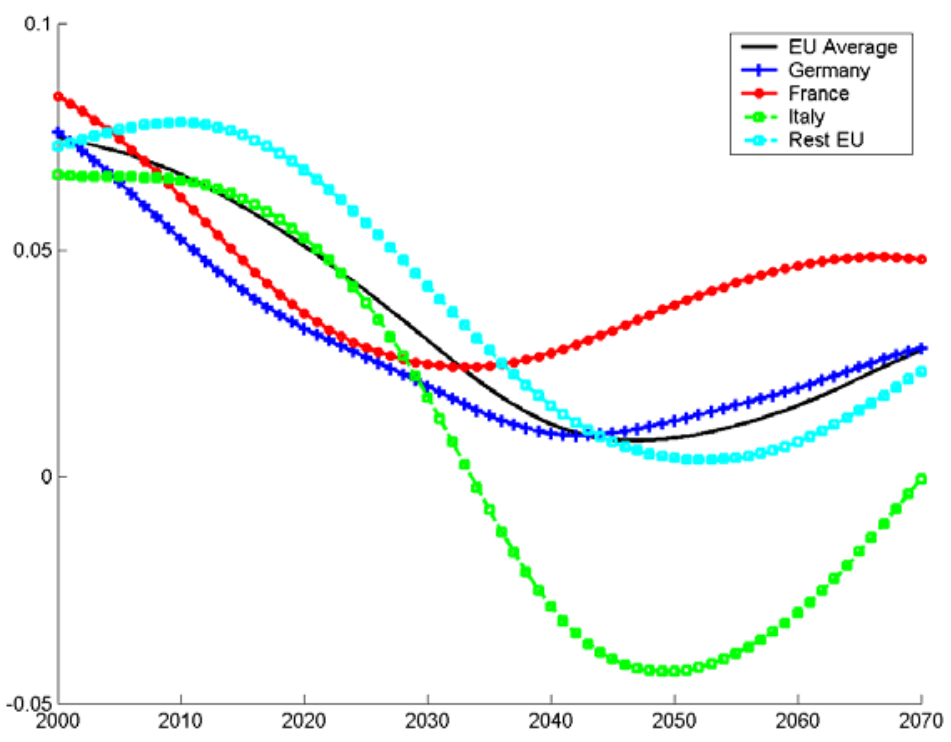

Figure 6b: Current account to output ratio (old system scenario)

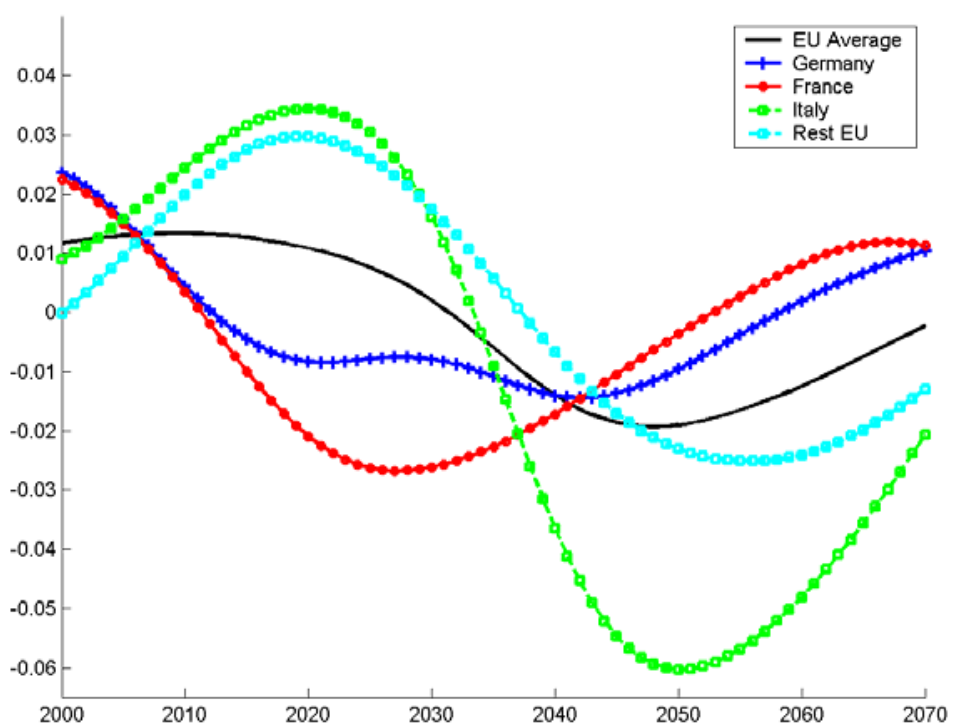

Notes: This figures show the projected saving rates and the current account to output ratios within countries of the European Union if capital mobility is restricted to the OECD area. EU Average: Average of all EU countries; Rest EU: all EU countries excluding France, Germany, and Italy.

Source: United Nations (2002), World Bank (2003), own calculations. 
Figure 7: Index of welfare differences between the reform and the old system scenarios

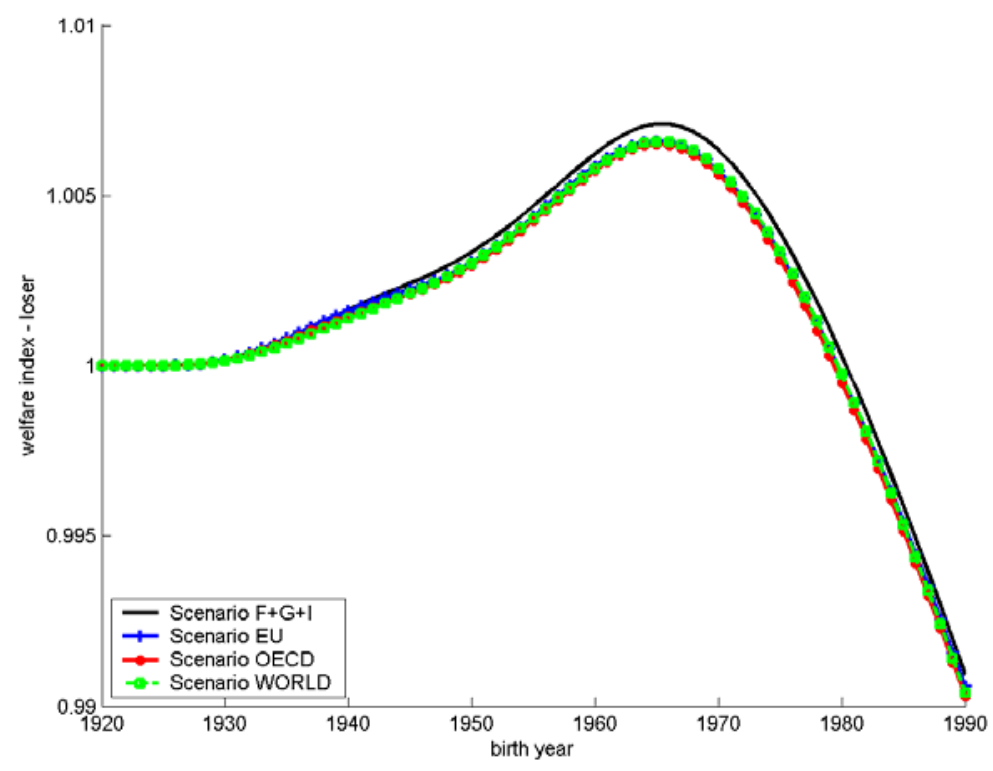

Notes: This figure shows the projected index of welfare differences between the old system scenario and the reform scenario for households living in Germany. Scenario F+G+I: perfect capital mobility within France, Germany, and Italy; Scenario EU: perfect capital mobility within the European Union; Scenario OECD: perfect capital mobility with the OECD; Scenario WORLD: perfect capital mobility across all world regions.

Source: United Nations (2002), World Bank (2003), own calculations. 
Figure 8: The influence of modeling endogenous labor supply: Saving rates and rate of return

Figure 8a: Saving rates: Difference between the reform and the old system scenarios

Endogenous labor supply

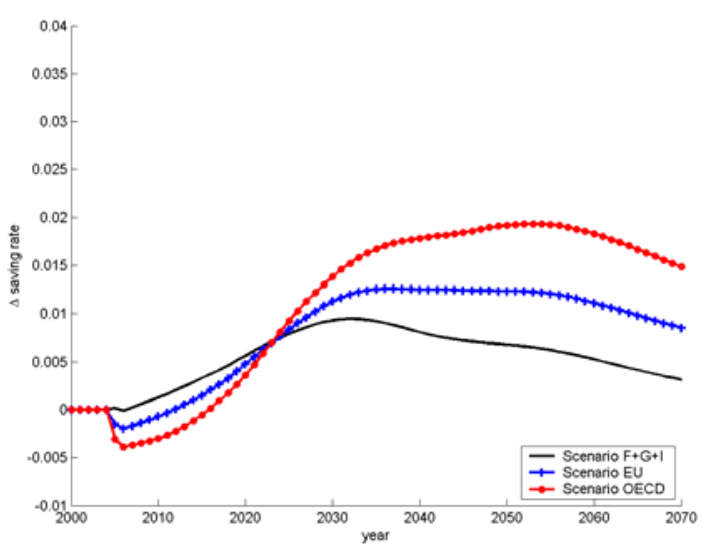

Exogenous labor supply

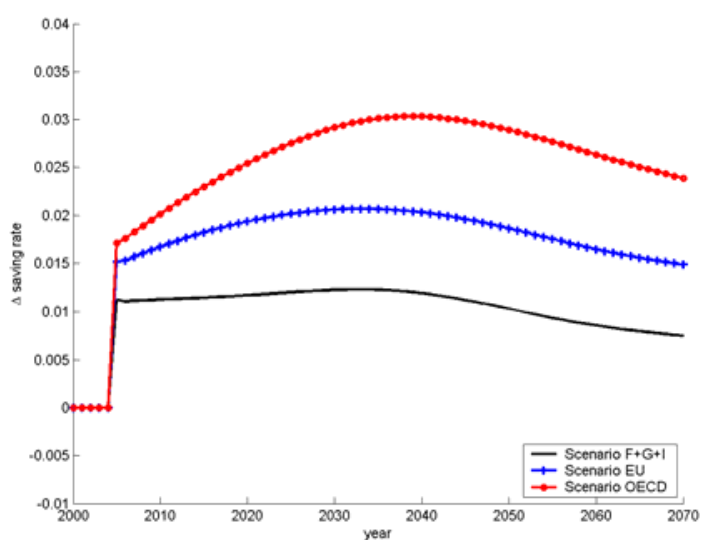

Figure 8b: Rate of return: Difference between the reform and the old system scenarios

Endogenous labor supply

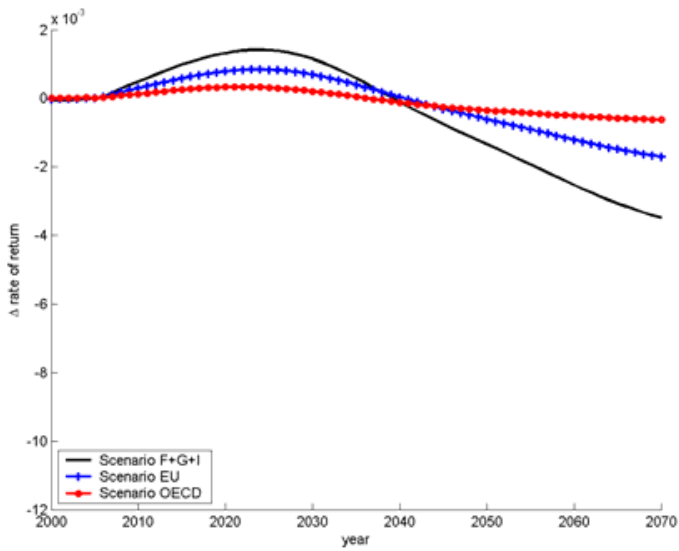

Exogenous labor supply

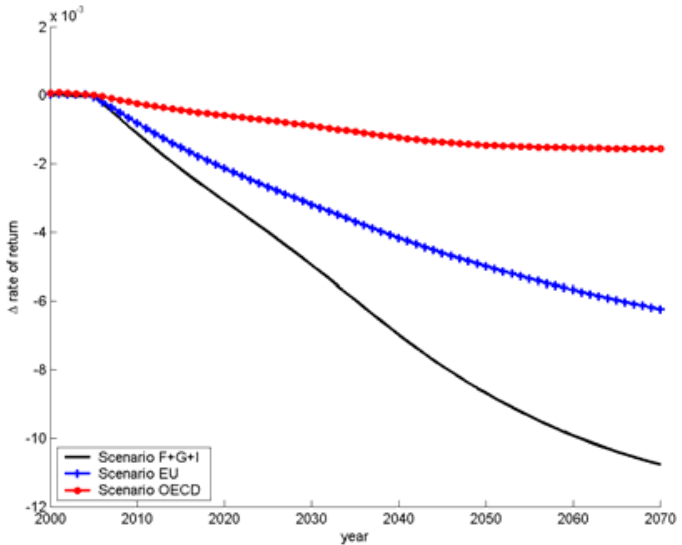

Notes: These figures show projections of the differential effects of the fundamental pension reform on saving rates and rates of return for the endogenous and the exogenous labor supply models of Section 6. F+G+I: France, Germany, and Italy; REST EU: the remaining countries of the European Union; USA+CAN: the United States and Canada; REST OECD: the remaining OECD countries.

Source: Own calculations, based on demographic projections of the United Nations (2002). 
Figure 9: Endogenous labor supply: The role of the intra-temporal substitution elasticity

Figure 9a: Difference in labor supply: Freezing versus pure PAYG

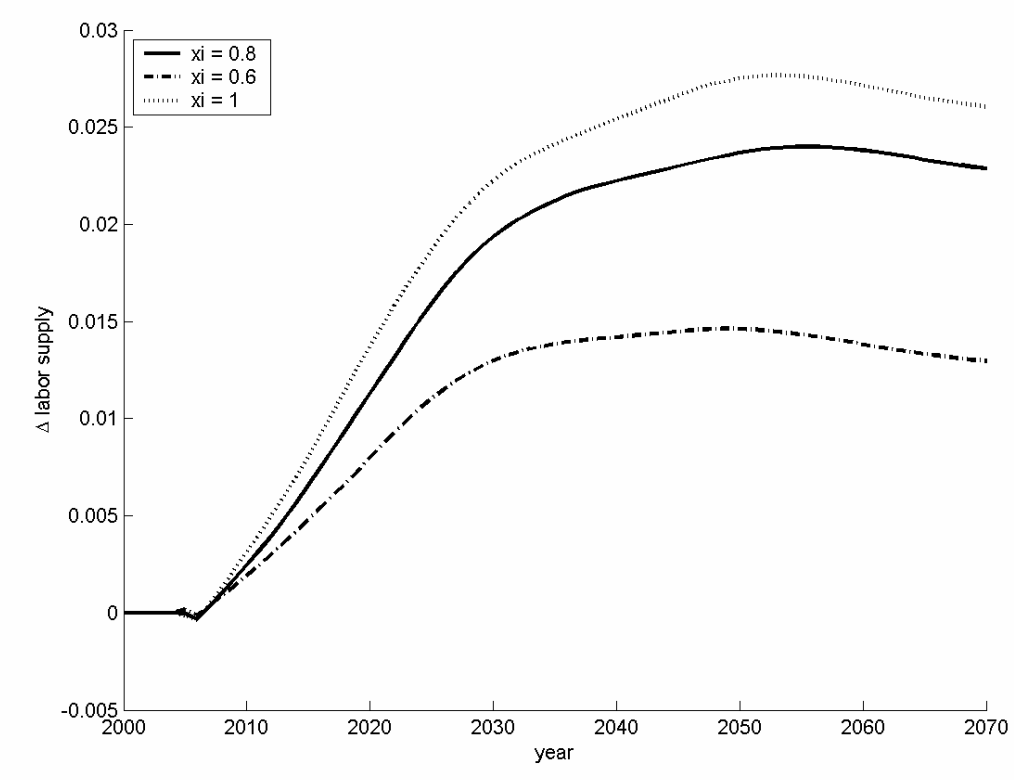

Figure 9b: Difference in the rate of return: Freezing versus pure PAYG

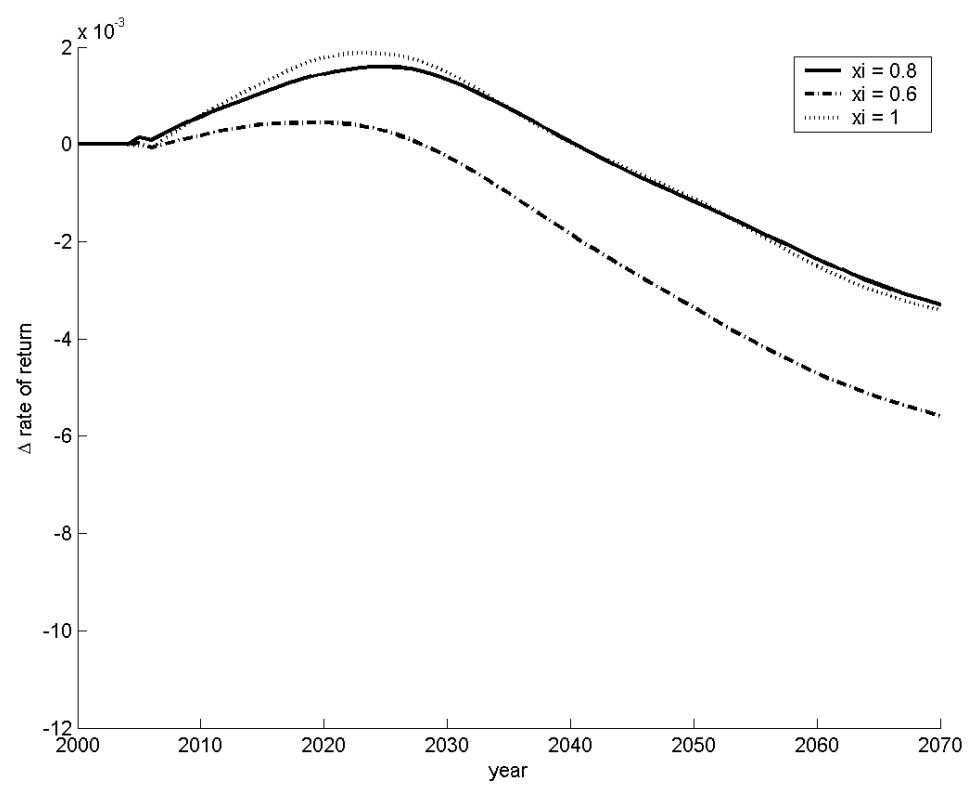

Notes: These figures show projected differences in labor supply and the rate of return to capital between the freezing and the pure PAYG scenario under the assumption that capital mobility is restricted to the FranceGermany-Italy region. Results are shown for alternative parameterizations of the intra-temporal substitution elasticity between consumption and leisure, $\xi$. 
Table 1: Calibration of parameters in the overlapping generations model

\begin{tabular}{lc}
\hline$\alpha$ : output share of capital in the CES production function & 0.35 \\
$g$ : growth rate of labor productivity & 0.015 \\
$\delta$ : depreciation rate of capital & 0.05 \\
$\psi$ : adjustment costs parameter & 1.5 \\
$\rho$ : rate of time preference & 0.011 \\
$\sigma$. coefficient of relative risk aversion & 2 \\
$\xi$ : intratemporal substitution elasticity & 0.8 \\
$\Omega_{i}$ : technology level & $0.05-0.07$ \\
$\bar{\omega}_{i}:$ consumption share parameter & $0.535-0.665$ \\
$\Delta \omega_{i}:$ increment of consumption share parameter & $0.015-0.02$ \\
\hline
\end{tabular}

Table 2: Predicted contribution and replacement rates of PAYG pension systems

\begin{tabular}{lcccccccccc}
\hline & \multicolumn{3}{c}{ France } & \multicolumn{3}{c}{ Germany } & \multicolumn{3}{c}{ Italy } \\
& 2000 & 2030 & 2050 & 2000 & 2030 & 2050 & 2000 & 2030 & 2050 \\
\hline $\begin{array}{l}\text { Old system scenario } \\
\text { Contribution rates }\end{array}$ & 0.275 & 0.356 & 0.375 & 0.268 & 0.375 & 0.415 & 0.325 & 0.476 & 0.534 \\
Net replacement rates & 0.654 & 0.654 & 0.654 & 0.7 & 0.7 & 0.7 & 0.646 & 0.646 & 0.646 \\
\hline Reform scenario & & & & & & & & & \\
Contribution rates & 0.275 & 0.295 & 0.295 & 0.268 & 0.294 & 0.294 & 0.325 & 0.34 & 0.34 \\
Net replacement rates & 0.654 & 0.549 & 0.513 & 0.7 & 0.568 & 0.504 & 0.646 & 0.489 & 0.415 \\
\hline
\end{tabular}

Notes: Figures shown in the table refer to the open economy scenario "OECD”. 